\title{
Atmospheric organic matter in clouds: exact masses and molecular formula identification using ultrahigh-resolution FT-ICR mass spectrometry
}

\author{
Y. Zhao ${ }^{1}$, A. G. Hallar ${ }^{2}$, and L. R. Mazzoleni ${ }^{1,3}$ \\ ${ }^{1}$ Department of Chemistry, Michigan Technological University, 1400 Townsend Drive, Houghton, MI 49931, USA \\ ${ }^{2}$ Division of Atmospheric Science, Desert Research Institute, Storm Peak Laboratory, Steamboat Springs, CO 80488, USA \\ ${ }^{3}$ Atmospheric Science Program, Michigan Technological University, 1400 Townsend Drive, Houghton, MI 49931, USA
}

Correspondence to: L. R. Mazzoleni (lrmazzol@mtu.edu)

Received: 17 July 2013 - Published in Atmos. Chem. Phys. Discuss.: 7 August 2013

Revised: 22 October 2013 - Accepted: 29 October 2013 - Published: 18 December 2013

\begin{abstract}
Clouds alter the composition of atmospheric aerosol by acting as a medium for interactions between gasand particulate-phase substances. To determine the cloud water atmospheric organic matter ( $\mathrm{AOM})$ composition and study the cloud processing of aerosols, two samples of supercooled clouds were collected at the Storm Peak Laboratory near Steamboat Springs, Colorado (3220 m a.s.1.). Approximately 3000 molecular formulas were assigned to ultrahighresolution mass spectra of the samples after using a reversedphase extraction procedure to isolate the AOM components from the cloud water. Nitrogen-containing compounds (CHNO compounds), sulfur-containing compounds (CHOS and CHNOS compounds) and other oxygen-containing compounds (CHO compounds) with molecular weights up to $700 \mathrm{Da}$ were observed. Average oxygen-to-carbon ratios of $\sim 0.6$ indicate a slightly more oxidized composition than most water-soluble organic carbon identified in aerosol studies, which may result from aqueous oxidation in the clouds. The AOM composition indicates significant influences from biogenic secondary organic aerosol (SOA) and residential wood combustion. We observed $60 \%$ of the cloud water $\mathrm{CHO}$ molecular formulas to be identical to SOA samples of $\alpha$-pinene, $\beta$-pinene, d-limonene, and $\beta$-caryophyllene ozonolysis. CHNO compounds had the highest number frequency and relative abundances and are associated with residential wood combustion and $\mathrm{NO}_{\mathrm{x}}$ oxidation. Multiple nitrogen atoms in the assigned molecular formulas for the nighttime cloud sample composite were observed, indicating the significance of nitrate radical reactions on the AOM
\end{abstract}

composition. Several CHOS and CHNOS compounds with reduced sulfur (in addition to the commonly observed oxidized sulfur-containing compounds) were also observed; however further investigation is needed to determine the origin of the reduced sulfur-containing compounds. Overall, the molecular composition determined using ultrahighresolution Fourier-transform ion cyclotron resonance (FTICR) mass spectrometry provides an unambiguous identification of the cloud water organic anion composition in the Rocky Mountain area that could help to improve the understanding of aqueous-phase processes.

\section{Introduction}

Cloud and fog droplets play a major role in the processing of atmospheric organic matter (AOM) (Blando and Turpin, 2000; Collett et al., 2008; Mazzoleni et al., 2010; Ervens et al., 2011; Herckes et al., 2013). Under conditions of high relative humidity, aerosol particles may act as cloud condensation nuclei $(\mathrm{CCN})$, where water vapor condenses onto them to form droplets. Suspended droplets are subject to gas-liquid equilibrium of volatile compounds and solidliquid equilibrium of non-volatile compounds (Graedel and Weschler, 1981), and thus new transport and transformation pathways affecting the composition of AOM may occur (Collett et al., 2008; Lim et al., 2010; Ervens et al., 2011). Volatile water-soluble compounds like glyoxal and methylglyoxal can readily transfer into the aqueous phase 
of droplets due to their high effective Henry's law constant (e.g., $H_{\text {eff }}=3.710 \times 10^{3} \mathrm{M} \mathrm{atm}^{-1}$ at $25^{\circ} \mathrm{C}$ for methylglyoxal (Betterton and Hoffmann, 1988)). Similarly, organic compounds in $\mathrm{CCN}$ aerosol can partition into the aqueous phase. Since water-soluble organic carbon (WSOC) may comprise up to $90 \%$ of the total organic carbon mass in aerosols (Samburova et al., 2013) and the particle activation process usually favors particles with a large fraction of watersoluble components (Facchini et al., 1999), a large fraction of the WSOC may partition to the aqueous phase. Thus a considerable number of species, either from the gas phase or the particle phase, can be found in the liquid phase of the droplets.

The multiphase environment of the droplets facilitates aqueous-phase reactions of the water-soluble species. A number of laboratory experiments mimicking wet aerosols showed that precursors like glyoxal or methylglyoxal react with inorganic species like ammonium nitrate or ammonium sulfate to produce a complex mixture of light-absorbing organic compounds (Carlton et al., 2007; De Haan et al., 2009; Galloway et al., 2009; Perri et al., 2009; Shapiro et al., 2009; Volkamer et al., 2009; Sareen et al., 2010; Sun et al., 2010). Likewise, a number of laboratory experiments have demonstrated the production of secondary organic compounds under cloud-relevant conditions (Tan et al., 2010; Yasmeen et al., 2010; Bateman et al., 2011), indicating cloud processing of AOM. In fact, in-cloud production of oxalic acid (Crahan et al., 2004), organic acids (Sorooshian et al., 2010), organosulfates (Pratt et al., 2013), and secondary organic aerosol (SOA; Wonaschuetz et al., 2012) has been observed in ambient measurements. Aerosol high-molecularweight compounds (also known as "oligomers") may also originate from aqueous-phase reactions (Altieri et al., 2008; De Haan et al., 2010; Lim et al., 2010; Yasmeen et al., 2010). Upon droplet evaporation (>90\% of cloud droplets evaporate; Pruppacher and Klett, 1996), aerosols with new composition are released. Volkamer et al. (2007) suggested missing aerosol aqueous-phase reactions or cloud processing may be the reason for the underpredictions of organic aerosol mass using atmospheric models (Heald et al., 2005; Yu et al., 2008). The aerosol mass burden and the oxygen-to-carbon $(\mathrm{O} / \mathrm{C})$ ratio of aged ambient organic aerosol are larger than that of SOA from a dry smog chamber (Aiken et al., 2008; $\mathrm{Ng}$ et al., 2010). Aqueous processing of the SOA could explain their high $\mathrm{O} / \mathrm{C}$ ratios (Ervens et al., 2011; Waxman et al., 2013). Therefore, it is crucial to study the composition of ambient cloud samples for a better understanding of SOA formation.

The composition of clouds and fog water has been studied for decades; however very little study of the high-molecularweight compounds in ambient cloud water has been done. Inorganic ions including $\mathrm{Na}^{+}, \mathrm{NH}_{4}^{+}, \mathrm{Mg}^{2+}, \mathrm{Ca}^{2+}, \mathrm{K}^{+}, \mathrm{Cl}^{-}$, $\mathrm{NO}_{3}^{-}, \mathrm{SO}_{4}^{2-}, \mathrm{Br}^{-}$, and $\mathrm{PO}_{4}^{3-}$ have been observed commonly in clouds at various places and seasons (Weathers et al., 1988;
Hindman et al., 1994; Deininger and Saxena, 1997; Collett et al., 2002; Simeonov et al., 2003; Lowenthal et al., 2004; Decesari et al., 2005; Gioda et al., 2011, 2013). Several lowmolecular-weight organic species have been studied and are believed to be transferred from the gas phase (Marinoni et al., 2004), including formic acid, acetic acid (Keene et al., 1995; Laj et al., 1997), formaldehyde (Keene et al., 1995; Munger et al., 1995; Laj et al., 1997), glyoxal, methylglyoxal (Munger et al., 1995), phenol, and nitrophenol (Lüttke and Levsen, 1997a; Lüttke et al., 1997). Dozens of other compounds were observed in clouds, mostly monocarboxylic acids, dicarboxylic acids, alcohols, and aldehydes (Limbeck and Puxbaum, 2000; Marinoni et al., 2004; van Pinxteren et al., 2005; Samy et al., 2010; Charbouillot et al., 2012). Usually the identified low-molecular-weight organics comprise a small fraction of the total organic mass in cloud water samples. For example, van Pinxteren et al. (2005) identified $\sim 20 \%$ of the dissolved organic carbon by measuring the individual organic compounds. Similarly, Facchini et al. (1999) measured $\sim 120$ individual organic compounds in fog water, which only accounted for on average less than $5 \%$ of total WSOC. Compounds similar to the high-molecular-weight organic compounds or HULIS found in aerosols (Havers et al., 1998; Graber and Rudich, 2006) were also recently observed in clouds (Feng and Möller, 2004; Decesari et al., 2005; Reyes-Rodríguez et al., 2009). For example, ReyesRodriguez et al. (2009) observed the high-molecular-weight organic compounds in cloud samples to be mostly aliphatic and oxygenated, with a small amount of aromatic compounds based on study of the functional groups. Overall, the previous studies either observed several individual compounds or observed functional groups rather than the complex mixture of the organic compounds on a molecular level.

Electrospray ionization (ESI) coupled with Fouriertransform ion cyclotron resonance (FT-ICR) mass spectrometry provides detailed molecular characterization of organic matter due to its extremely high resolution and mass accuracy (Marshall et al., 1998; Kujawinski, 2002; Sleighter and Hatcher, 2007). ESI is a soft ionization method that minimizes the fragmentation of analytes, allowing for detection of intact molecules, while the ultrahigh resolution and high accuracy of FT-ICR allows for assignment of a unique chemical formula to each peak detected. FT-ICR mass spectrometry has been successfully applied to ambient fog water samples (Mazzoleni et al., 2010; LeClair et al., 2012), rainwater samples (Altieri et al., 2009a, b, 2012), and aerosols (Reemtsma et al., 2006; Wozniak et al., 2008; Laskin et al., 2009; Schmitt-Kopplin et al., 2010; Lin et al., 2012b; Mazzoleni et al., 2012). This powerful analytical approach was applied in this study to characterize the complex mixture of higher molecular weight water-soluble organic compounds in ambient cloud water samples collected at the Storm Peak Laboratory (SPL). Here we present the results of ultrahigh-resolution FT-ICR mass spectrometry of two supercooled cloud samples collected in February 2010. 
The comprehensive characterization of the cloud water AOM composition after negative ion ESI FT-ICR mass spectrometry will be discussed.

\section{Methods}

\subsection{Cloud water sample collection}

To investigate the composition of cloud water AOM, samples of ambient clouds consisting of supercooled droplets were collected at the SPL. The remote continental site is located on the western summit of Mt. Werner (3220 m a.s.l.) in the Park Range Colorado near Steamboat Springs. The mountain-top laboratory facilitates observations of free-tropospheric air and in-cloud conditions. SPL is situated at the tree line on a $70 \mathrm{~km}$ ridge oriented perpendicular to the prevailing westerly winds (Hallar et al., 2013). SPL experiences transport from distant sources including urban areas, power plants, and wildfires (Obrist et al., 2008). There are also abundant monoterpene emissions from the pine trees at SPL during summer months (Amin et al., 2012). Clouds that surround the SPL with supercooled droplets form in the wintertime (Lowenthal et al., 2002). A custom cloud sieve with stainless steel strands of $0.5 \mathrm{~mm}$ diameters was used to collect supercooled droplets by impaction (Fig. S1). As described by Hindman et al. (1992), cloud droplets with diameter $>8 \mu \mathrm{m}$ will be collected with a $50 \%$ collection efficiency on the $0.5 \mathrm{~mm}$ strand diameter with an average wind speed of $2 \mathrm{~m} \mathrm{~s}^{-1}$ (average wind speed during sample collection time periods). Cloud sieves were mounted on the SPL rooftop deck railing on the west side during cloud events. After $\sim 20 \mathrm{~min}$, the cloud sieves were carried into a cold laboratory space to remove the frozen cloud water (collected as rime) from the strands using a stainless steel blade and collection tray. The collected rime was stored in a freezer at $-5^{\circ} \mathrm{C}$. Four cloud water samples were collected during short separate cloud events. The first sample (CW1) is a composite of two samples collected between 20:30 and 21:00 LT on 24 February 2010 and 07:00 and 08:00 LT on 25 February 2010. The second composite sample (CW2) is a composite of two samples, collected between 08:00 and 11:00 LT on 26 February 2010 . The $24 \mathrm{~h}$ air back trajectory analyses showed the air coming from the west and northwest of SPL (Figs. S2 and S3). The particle concentrations (with diameter $>3 \mathrm{~nm}$ ) were around $1000 \mathrm{~cm}^{-3}$ during the sampling time determined by the condensation particle counter (TSI, model \#3025). One field blank sample was prepared by leaving the cloud sieve in the air in the absence of a cloud event and then rinsed with high-purity water.

\subsection{Sample preparation}

Cloud water samples were prepared for analysis using a reversed-phase solid-phase extraction (SPE) method to concentrate the analytes and remove inorganic ions (Mazzoleni et al., 2010). The Strata-X (Phenomenex) cartridges, with both hydrophilic and hydrophobic functional groups, were found to obtain a diverse spectrum of analytes. Strata-X SPE cartridges were conditioned with consecutive application of the following: $1 \mathrm{~mL}$ of isopropyl alcohol, $2 \mathrm{~mL}$ of acetonitrile, $2 \mathrm{~mL}$ of acidified methanol-containing $0.1 \%$ formic acid, and $2 \mathrm{~mL}$ of aqueous $0.1 \%$ formic acid. Then $100 \mathrm{~mL}$ of cloud water without $\mathrm{pH}$ adjustment was applied at a rate of $1-2 \mathrm{~mL} \mathrm{~min}^{-1}$ to the cartridge to allow the AOM components to partition to the SPE stationary phase. $\mathrm{pH}$ values of the cloud water samples were not determined in this study. Hindman et al. (2006) measured the $\mathrm{pH}$ values of wintertime clouds collected at Storm Peak Laboratory from 1983 to 2004 and reported a pH range of 3.7 to 5.7 ; thus the cloud samples in this study are expected to be acidic. The cartridges were rinsed with high-purity acidified water to remove salts and subsequently dried. Some of the low-molecular-weight analytes $(<100 \mathrm{Da})$ are expected to be lost in this step (Samburova et al., 2013). Analytes were eluted with $1.5 \mathrm{~mL}$ of acetonitrile. Extraction recoveries were not determined in this study, however a large fraction of the high-molecular-weight cloud water organic carbon is expected to be present due to the both hydrophilic and hydrophobic characteristics of the Strata-X cartridges. The field blank and lab blank were prepared using the same method except that $100 \mathrm{~mL}$ of highpurity water without $\mathrm{pH}$ adjustment was applied to the SPE cartridge for the lab blank. All solvents were HPLC grade or higher. Prepared samples were stored at $-5^{\circ} \mathrm{C}$ until further analysis.

\subsection{Instrumental parameters}

Ultrahigh-resolution mass spectrometry analysis was performed using a hybrid linear ion trap FT-ICR mass spectrometer (LTQ FT Ultra, Thermo Scientific) equipped with an ESI source. Cloud water samples were infused directly into the ESI interface, and the ESI parameters were adjusted to obtain a stable ion current with minimum ion injection time into the mass analyzer. After optimization, the infusion flow rate was $4 \mu \mathrm{L} \mathrm{min}^{-1}$, the ESI needle voltage was $-3.7 \mathrm{kV}$, and the capillary temperature was $265^{\circ} \mathrm{C}$. Besides the instrumental parameters, the electrospray efficiencies of the analytes depend on their chemical structures. Analytes with hydroxyl or carboxyl functional groups favor ionization in the negative ion electrospray mode. Many water-soluble organic species in clouds contain these hydrophilic functional groups, and thus most of the cloud water organic carbon species are expected to be observed in the negative ion mass spectra, though not all the organic carbon species are ionized. The sample delivery apparatus was flushed in between each analysis with a minimum of $500 \mu \mathrm{L}$ of acetonitrile and water $(50: 50)$ and $500 \mu \mathrm{L}$ of $100 \%$ acetonitrile until background noise levels were reached. Negative ion mass spectra were collected using full-scan analysis for the range of $100<\mathrm{m} / z$ $<1000$. Mass resolving power, $\mathrm{m} / \Delta m_{50 \%}$, in which $\Delta m_{50 \%}$ 
is peak full width at half-maximum peak height, was set at 200000 (at $\mathrm{m} / \mathrm{z}$ 400) for all spectra. Automatic gain control was used to consistently fill the LTQ with the same number of ions $\left(n=10^{6}\right)$ for each acquisition and to avoid space charge effects from overfilling the mass analyzer. The instrument was externally calibrated in negative ion mode with a standard solution of sodium dodecyl sulfate and taurocholic acid. The resulting mass accuracy was better than $2 \mathrm{ppm}$. Over 200 individual mass spectra recorded in the time domain were collected and stored as transients for each sample using Thermo Xcalibur software.

\subsection{Data processing and assignment of molecular formula composition}

Ultrahigh-resolution FT-ICR mass spectra were postprocessed using Composer software (Sierra Analytics, version 1.0.5) as previously described in Putman et al. (2012) and Mazzoleni et al. (2012). Briefly, approximately 200 transients were co-added to improve analysis detection (Kujawinski et al., 2002; Stenson et al., 2003). Internal recalibration of the mass spectra (Sleighter and Hatcher, 2008) was performed to improve the molecular formula assignment accuracy. A set of naturally occurring cloud water analytes from the two cloud water samples was selected to represent internal recalibrants over the mass range of 100-650 Da. The match tolerances for the internal recalibrants were set at 3 ppm with a minimum relative abundance (RA) of 18 times the root mean square (RMS) of the signal-to-noise ratio between the range $m / z$ 900-1000, (RMS of signal-to-noise ratio was $0.018 \%$ for CW1 and $0.038 \%$ for CW2). The list of internal recalibrants is given in Table $\mathrm{S} 1$ in the Supplement.

The molecular formula calculator was set to allow up to 70 carbon $(\mathrm{C}), 140$ hydrogen $(\mathrm{H}), 25$ oxygen $(\mathrm{O}), 4$ nitrogen $(\mathrm{N})$, and 1 sulfur $(\mathrm{S})$ per molecular formula composition. The calculator is based on the PREDATOR algorithm (Blakney et al., 2011) and uses a Kendrick mass defect (KMD) analysis (Hughey et al., 2001) to sort ions into $\mathrm{CH}_{2}$ homologous series (species with a specific number of double bond equivalents (DBE) and heteroatom content) and then assigns the "de novo" molecular formulas $\leq 500 \mathrm{Da}$. The KMD analysis is determined from Eqs. (1) and (2) (Hughey et al., 2001):

$$
\begin{aligned}
\text { Kendrick mass }(\mathrm{KM}) & =(\text { measured mass }) \\
& \times(14.00000) /(14.01565),
\end{aligned}
$$

$\mathrm{KMD}=$ nominal Kendrick mass $(\mathrm{NKM})-\mathrm{KM}$.

Using these equations, compounds of the same $\mathrm{CH}_{2}$ homologous series will have the same KMD. An assignment threshold of 6 times the RMS of the signal-to-noise ratio was applied to the detected anions. The molecular formulas resulting in measurement errors $>3$ ppm were discarded. Additional data filtering of the assigned formulas was done by applying the rules and assumptions as described by Koch et al. (2005). The procedures applicable to atmospheric samples are described in more detail in Putman et al. (2012). DBE is determined by Eq. (3) (McLafferty and Tureek, 1993):

$\mathrm{DBE}=c-h / 2+n / 2+1$

for each elemental composition $\mathrm{C}_{c} \mathrm{H}_{h} \mathrm{~N}_{n} \mathrm{O}_{o} \mathrm{~S}_{s} . \mathrm{S}$ and $\mathrm{O}$ are divalent and $\mathrm{N}$ is trivalent in Eq. (3). Thus, the additional double bonds formed by tetravalent and hexavalent $S$ or pentavalent $\mathrm{N}$ are not represented in the DBE calculations (Mazzoleni et al., 2012).

Molecular formulas were assigned to the field and lab blank samples using the same method. The blank mass spectra contained several low-molecular-weight negative ions $(m / z<400)$, most of which were assigned unambiguous molecular formulas as described above. Approximately 800 of the assigned monoisotopic formulas were in common with the cloud water samples CW1 and CW2. The common formulas represent approximately $20 \%$ of the assigned molecular formulas in cloud water samples. Although some carryover of the sample components to blanks may have occurred (Mazzoleni et al., 2012), other sources of contamination could not be ruled out. Thus, all of the common molecular formulas assigned to negative ions in either of the blank samples were removed from the presented cloud water composition.

\section{Results and discussion}

\subsection{Mass spectra and molecular formula assignments}

Molecular formulas of the form $\mathrm{C}_{c} \mathrm{H}_{h} \mathrm{~N}_{n} \mathrm{O}_{o} \mathrm{~S}_{S}$ were assigned to the negative ion ultrahigh-resolution FT-ICR mass spectra of AOM extracted from cloud water samples. Overall, $82-83 \%$ of the total ion current of the CW1 and CW2 sample mass spectra were assigned. After blank subtraction and quality assurance filtering, approximately 3000 monoisotopic molecular formulas were unambiguously identified for CW1 and CW2 (Table 1). Assignments of corresponding polyisotopic molecular formulas containing ${ }^{13} \mathrm{C}$ were observed for $71 \%$ and $69 \%$ of the formulas assigned to CW1 and CW2, respectively. Likewise, polyisotopic molecular formulas with ${ }^{34} \mathrm{~S}$ were observed for $54 \%$ and $50 \%$ of the Scontaining molecular formulas assigned to CW1 and CW2. Detection of polyisotopic anions is more limited than detection of monoisotopic anions due to the lower RA, which reflects the natural abundances of ${ }^{13} \mathrm{C}$ at $1 \%$ and ${ }^{34} \mathrm{~S}$ at $4 \%$. The high number frequency of corresponding polyisotopic molecular formulas with ${ }^{13} \mathrm{C}$ at exactly $1.0034 \mathrm{Da}$ higher than the monoisotopic molecular formulas confirms the molecular formula assignment and the singly charged state of the detected anions. No evidence of multiply charged species was observed. 
Reconstructed mass spectra of the monoisotopic molecular formulas assigned to the cloud water samples after blank subtraction are shown in Fig. 1. In both of the cloud water mass spectra, the anions occupy a mass range of 100-700 Da, covering both the range of previously identified cloud water carbonyl species (Limbeck and Puxbaum, 2000; Marinoni et al., 2004; van Pinxteren et al., 2005; Samy et al., 2010; Charbouillot et al., 2012) and the range of water-soluble macromolecular compounds also known as "HULIS" (Feng and Möller, 2004). Macromolecular compounds were also observed in fog water by several studies (Krivacsy et al., 2000; Herckes et al., 2002a, b; Cappiello et al., 2003). Similar to the ambient aerosol collected at this site, the highest RA anions were observed between $m / z$ 200-400 (Mazzoleni et al., 2012). Consistent with the ultrahigh-resolution mass spectra of other atmospheric samples like aerosols (Wozniak et al., 2008; Schmitt-Kopplin et al., 2010), fog water (Mazzoleni et al., 2010; LeClair et al., 2012), and rainwater (Altieri et al., 2009b, 2012), the mass spectra for cloud water samples are quite complex with a high number of isobaric anions. An example of the isobaric complexity with 14 molecular formulas within $0.25 \mathrm{Da}$ is shown in an excerpt of the reconstructed CW1 mass spectrum (Fig. 1b).

Four subgroups of molecular formulas were determined based on their elemental composition; they include compounds containing only $\mathrm{C}, \mathrm{H}$, and $\mathrm{O}(\mathrm{CHO})$; compounds containing $\mathrm{C}, \mathrm{H}, \mathrm{N}$, and $\mathrm{O}(\mathrm{CHNO})$; compounds containing $\mathrm{C}$, $\mathrm{H}, \mathrm{O}$, and $\mathrm{S}(\mathrm{CHOS})$; and compounds containing $\mathrm{C}, \mathrm{H}, \mathrm{N}, \mathrm{O}$, and $\mathrm{S}$ (CHNOS). The $\mathrm{CHO}$ compounds ( $\mathrm{N}=840$ and 712$)$ represented $\sim 26 \%$ of the total number of assigned molecular formulas from the CW1 and CW2 sample mass spectra (Fig. 1c, e). In general, a clear pattern of mass differences of the CHO compounds can be seen in both of the mass spectra (blue peaks in Fig. 1) with spacing of the high-intensity anions of $14 \mathrm{Da}$. This has been commonly observed in natural organic matter samples (Stenson et al., 2003; Koch et al., 2007; Mazzoleni et al., 2010). This pattern is a likely consequence of the naturally occurring $\mathrm{CH}_{2}$ "homologous series" or formula extensions in organic matter (Hughey et al., 2001). All of the identified CHO molecular formulas belong to a $\mathrm{CH}_{2}$ homologous series (Fig. 2). The series range from 2 to 26 molecular formulas in length, with an average length of $\sim 10$. However, it should be noted that the addition of the $-\mathrm{CH}_{2}$ to a molecular formula does not necessary lengthen the compounds' carbon backbone, but may appear in any aspect of the compounds' molecular structure. Moreover, each molecular formula identified may represent several organic compounds with different chemical structures (Hertkorn et al., 2008). Therefore, the clouds have extremly complex organic composition considering the $\sim 3000$ molecular formulas identified in each sample. In previous studies, the $\mathrm{CHO}$ compounds typically represented the highest number fraction of the overall compounds (Wozniak et al., 2008; Schmitt-Kopplin et al., 2010; Altieri et al., 2012; Mazzoleni et al., 2012). However in this study, CHNO compounds (N
$=1638$ and 1431) are the most frequently observed compounds in both cloud water samples and represented $>50 \%$ of the total number of molecular formulas (Fig. 1c and 1e). From the mass spectra, the CHNO compounds (red peaks in Fig. 1) with the highest relative abundances are in the mass range of $m / z 200-400$ and the highest density is in the mass range of $m / z$ 300-600. Consistent with the CHO compounds, a wide number of $\mathrm{CH}_{2}$ homologous series were observed in the cloud water CHNO compounds (Fig. 2). The S-containing compounds (CHOS and CHNOS) represented $\sim 21 \%$ of the total number of molecular formulas (Fig. 1c, e). In CW1, 281 CHOS and 381 CHNOS molecular formulas were identified, and in CW2, $221 \mathrm{CHOS}$ and $360 \mathrm{CHNOS}$ formulas were identified. Typically the S-containing compounds (green peaks in Fig. 1) are in the mass range of 200 $<m / z<600$. Often the relative abundances of these compounds are lower than the compounds in other groups. The $\mathrm{CH}_{2}$ homologous series of the S-containing compounds are less clear in the reconstructed mass spectra. However, they are clearly shown in the KMD plots (Fig. 2). The composition and molecular properties for each of the subgroups will be discussed further in the following sections.

\subsection{Compounds containing only $\mathrm{C}, \mathrm{H}$, and $\mathrm{O}$}

Oxygen-to-carbon ratios $(\mathrm{O} / \mathrm{C})$ and hydrogen-to-carbon ratios $(\mathrm{H} / \mathrm{C})$ are commonly used to describe the chemical properties of aerosol (Aiken et al., 2007, 2008; Jimenez et al., 2009; Bateman et al., 2010; Kroll et al., 2011). In general, $\mathrm{O} / \mathrm{C}$ represents the degree of oxidation and $\mathrm{H} / \mathrm{C}$ reflects the degree of saturation of the composition studied. The $\mathrm{O} / \mathrm{C}$ and $\mathrm{H} / \mathrm{C}$ elemental ratios of the individual $\mathrm{CHO}$ compounds of the cloud water samples are plotted in Fig. 3a (for CW1) and Fig. S4a (for CW2). The van Krevelen diagram (O/C vs. H/C) indicates the oxidation, hydration, hydrogenation, and alkylation relationships between the observed molecular formulas (Kim et al., 2003; Wu et al., 2004; Heald et al., 2010). In Fig. 3a and S4a, we plotted simultaneously the analyte isoabundance and individual points for each of the $\mathrm{CHO}$ molecular formulas. This permits visualization of the $\mathrm{CH}_{2}$ homologous series of molecular formulas in lines pointing to the upper left corner $(\mathrm{H} / \mathrm{C}=2.0)$ of the plot as well as their significance in terms of isoabundance. In both samples, the majority of the $\mathrm{CHO}$ compounds have $\mathrm{O} / \mathrm{C}$ ratios $<1.0$ and $\mathrm{H} / \mathrm{C}$ ratio from 0.5 to 2.0 . The highest intensity molecular formulas are in the vicinity of $\mathrm{O} / \mathrm{C}=0.5$ and $\mathrm{H} / \mathrm{C}$ $=1.5$. Interestingly, there are several compounds with $\mathrm{O} / \mathrm{C}$ ratios $>1.0$ in both samples and many of these have 18-22 oxygen atoms and molecular weights of 400-500 Da. These highly oxidized high-molecular-weight compounds may be the products of aqueous-phase reactions (Lee et al., 2011). In addition, a few $\mathrm{CHO}$ compounds are located in the lower left corner of the van Krevelen diagram $(\mathrm{O} / \mathrm{C}<0.3, \mathrm{H} / \mathrm{C}$ $<1)$. These appear to be aromatic compounds with high DBE values. Examples of the molecular formulas in this 
Table 1. Cloud water composition characteristics by elemental groups.

\begin{tabular}{|c|c|c|c|c|c|c|}
\hline & & All & $\mathrm{CHO}$ & CHNO & CHOS & CHNOS \\
\hline \multirow{9}{*}{ CW1 } & Number frequency & 3140 & 840 & 1638 & 281 & 381 \\
\hline & $\mathrm{O} / \mathrm{C}$ & $0.62 \pm 0.37$ & $0.54 \pm 0.35$ & $0.72 \pm 0.34$ & $0.45 \pm 0.38$ & $0.45 \pm 0.34$ \\
\hline & $\mathrm{O} / \mathrm{C}_{\mathrm{w}}$ & $0.63 \pm 0.03$ & $0.47 \pm 0.04$ & $0.77 \pm 0.04$ & $0.43 \pm 0.09$ & $0.44 \pm 0.04$ \\
\hline & $\mathrm{H} / \mathrm{C}$ & $1.46 \pm 0.36$ & $1.42 \pm 0.36$ & $1.56 \pm 0.29$ & $1.37 \pm 0.45$ & $1.21 \pm 0.41$ \\
\hline & $\mathrm{H} / \mathrm{C}_{\mathrm{W}}$ & $1.53 \pm 0.07$ & $1.48 \pm 0.11$ & $1.61 \pm 0.10$ & $1.41 \pm 0.27$ & $1.17 \pm 0.10$ \\
\hline & DBE & $6.30 \pm 3.37$ & $6.36 \pm 3.56$ & $5.58 \pm 2.62$ & $6.76 \pm 4.21$ & $8.98 \pm 3.72$ \\
\hline & $\mathrm{DBE}_{\mathrm{W}}$ & $5.19 \pm 0.19$ & $5.50 \pm 0.35$ & $4.63 \pm 0.22$ & $5.56 \pm 0.92$ & $8.64 \pm 0.53$ \\
\hline & $\mathrm{OM} / \mathrm{OC}$ & $2.08 \pm 0.56$ & $1.83 \pm 0.47$ & $2.25 \pm 0.54$ & $1.89 \pm 0.56$ & $2.02 \pm 0.53$ \\
\hline & $\mathrm{OM} / \mathrm{OC}_{\mathrm{w}}$ & $2.20 \pm 0.06$ & $1.79 \pm 0.09$ & $2.44 \pm 0.08$ & $1.98 \pm 0.23$ & $2.14 \pm 0.11$ \\
\hline \multirow{9}{*}{ CW2 } & Number frequency & 2724 & 712 & 1431 & 221 & 360 \\
\hline & $\mathrm{O} / \mathrm{C}$ & $0.61 \pm 0.34$ & $0.51 \pm 0.28$ & $0.73 \pm 0.31$ & $0.43 \pm 0.37$ & $0.43 \pm 0.35$ \\
\hline & $\mathrm{O} / \mathrm{C}_{\mathrm{w}}$ & $0.63 \pm 0.02$ & $0.47 \pm 0.03$ & $0.74 \pm 0.04$ & $0.42 \pm 0.05$ & $0.43 \pm 0.04$ \\
\hline & $\mathrm{H} / \mathrm{C}$ & $1.46 \pm 0.35$ & $1.41 \pm 0.34$ & $1.56 \pm 0.30$ & $1.40 \pm 0.44$ & $1.21 \pm 0.37$ \\
\hline & $\mathrm{H} / \mathrm{C}_{\mathrm{w}}$ & $1.53 \pm 0.06$ & $1.46 \pm 0.11$ & $1.61 \pm 0.09$ & $1.41 \pm 0.17$ & $1.19 \pm 0.11$ \\
\hline & DBE & $6.29 \pm 3.29$ & $6.35 \pm 3.18$ & $5.60 \pm 2.84$ & $6.35 \pm 3.89$ & $8.89 \pm 3.42$ \\
\hline & $\mathrm{DBE}_{\mathrm{W}}$ & $5.25 \pm 0.18$ & $5.64 \pm 0.32$ & $4.75 \pm 0.22$ & $5.52 \pm 0.55$ & $8.00 \pm 0.52$ \\
\hline & $\mathrm{OM} / \mathrm{OC}$ & $2.06 \pm 0.52$ & $1.79 \pm 0.37$ & $2.25 \pm 0.50$ & $1.86 \pm 0.54$ & $1.99 \pm 0.55$ \\
\hline & $\mathrm{OM} / \mathrm{OC}_{\mathrm{w}}$ & $2.16 \pm 0.05$ & $1.78 \pm 0.08$ & $2.35 \pm 0.08$ & $1.96 \pm 0.14$ & $2.18 \pm 0.11$ \\
\hline
\end{tabular}

Note: average values $(\mathrm{O} / \mathrm{C}, \mathrm{H} / \mathrm{C}, \mathrm{DBE}$, and $\mathrm{OM} / \mathrm{OC})$ are the mean and standard deviation of each data subset. Relative-abundance-weighted values $\left(\mathrm{O} / \mathrm{C}_{\mathrm{W}}, \mathrm{H} / \mathrm{C}_{\mathrm{W}}, \mathrm{DBE}_{\mathrm{W}}\right.$, and $\left.\mathrm{OM} / \mathrm{OC}_{\mathrm{W}}\right)$ were determined using Eq. (S1) to Eq. (S4) and have propagated standard error using the standard deviations for each subset.

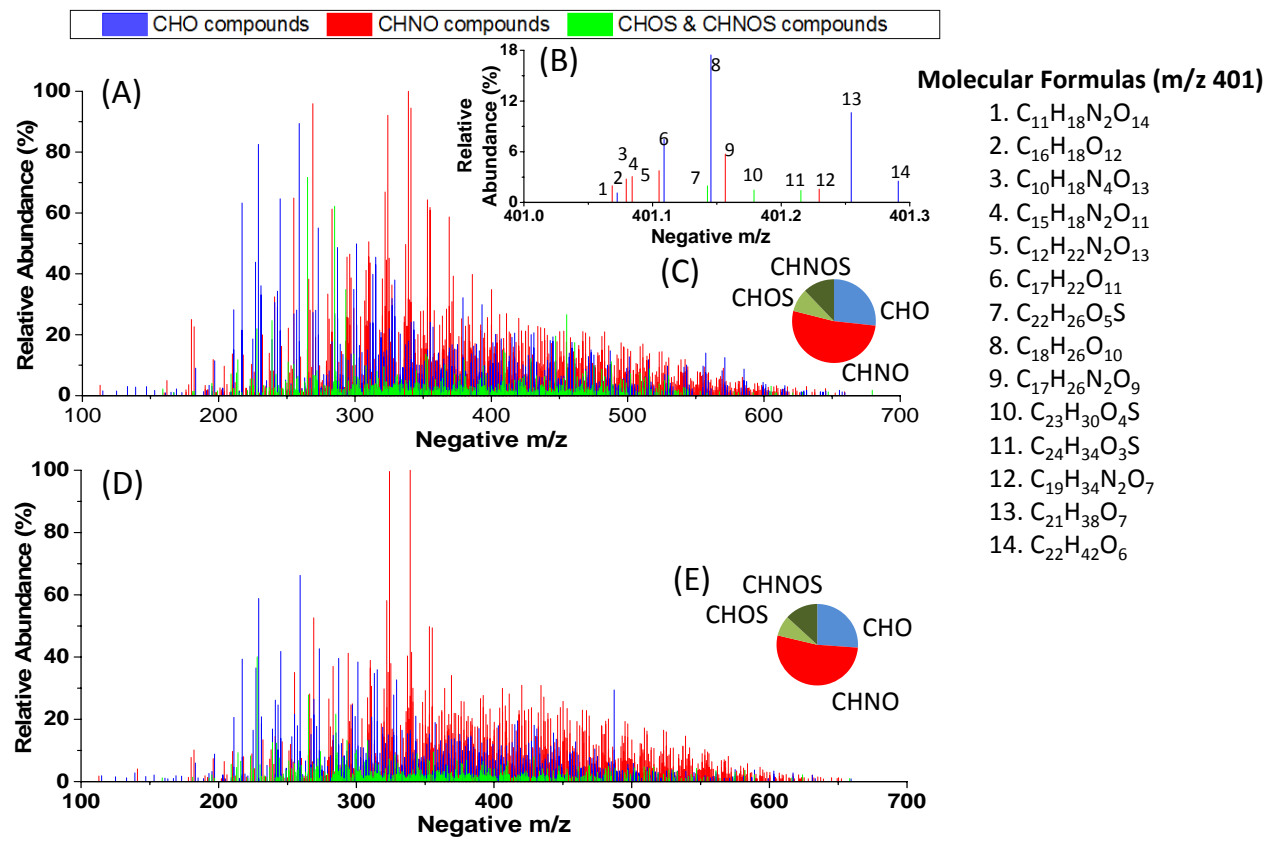

Fig. 1. Reconstructed mass spectra of the identified monoisotopic molecular formulas for CW1 (a) and (b) and CW2 (d): an excerpt of the CW1 mass spectrum from $\mathrm{m} / \mathrm{z} 401.00$ to 401.30 is shown in (b) with a list of the numbered analytes and their identified molecular formulas. Pie charts indicate the number fraction of the identified monoisotopic molecular formula groups for CW1 (c) and CW2 (e).

region include the homologous series of $\mathrm{C}_{20} \mathrm{H}_{8} \mathrm{O}_{4}\left(\mathrm{CH}_{2}\right)_{1-7}$ and $\mathrm{C}_{19} \mathrm{H}_{6} \mathrm{O}_{5}\left(\mathrm{CH}_{2}\right)_{1-6}$. The average $\mathrm{O} / \mathrm{C}$ ratios for the $\mathrm{CW} 1$ and $\mathrm{CW} 2 \mathrm{CHO}$ compounds are $0.54( \pm 0.35)$ and 0.51 $( \pm 0.28)$ (Table 1). Likewise, the average $\mathrm{H} / \mathrm{C}$ ratios are 1.42
( \pm 0.36$)$ and $1.41( \pm 0.34)$. Similarly, Altieri et al. (2009b) observed an average $\mathrm{O} / \mathrm{C}$ ratio of $0.7( \pm 0.5)$ and an average $\mathrm{H} / \mathrm{C}$ ratio of $1.5( \pm 0.4)$ for the $\mathrm{CHO}$ compounds in ambient rainwater. Thus, the $\mathrm{CHO}$ compounds reported here are 


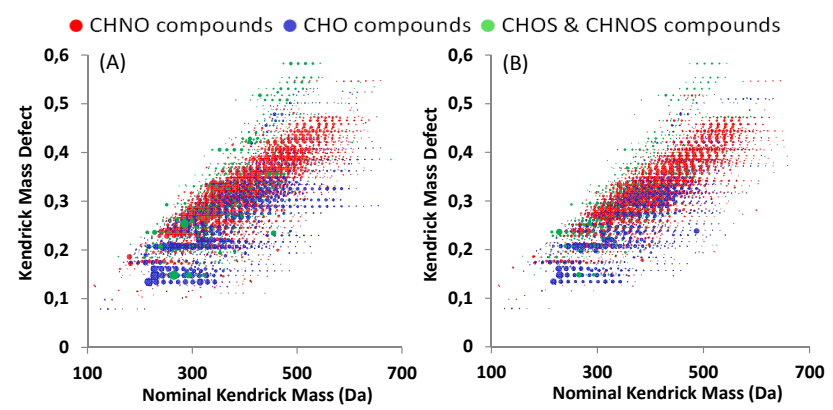

Fig. 2. The Kendrick mass defect vs. nominal Kendrick mass for the monoisotopic molecular formulas identified in CW1 (a) and CW2 (b), with scaled symbol sizes representing the relative abundance of the compounds.

less oxidized and somewhat less saturated, likely reflecting seasonal differences and cloud processing time differences. Other reported elemental ratios for $\mathrm{CHO}$ compounds in ambient aerosol water-soluble organic compounds include 0.47 $( \pm 0.2)$ and $1.42( \pm 0.3)$ (Mazzoleni et al., 2012), 0.6 and 1.69 (Rincon et al., 2012), and $0.40( \pm 0.21)$ and $1.29( \pm 0.35)$ (Lin et al., 2012a). Note that the solid-phase extraction step used in this study may not retain well some of the low-molecularweight $\mathrm{CHO}$ compounds like formic acid, acetic acid, or oxalic acid, which usually have high $\mathrm{O} / \mathrm{C}$ ratios $(>1)$. Thus, the $\mathrm{O} / \mathrm{C}$ ratios of the clouds may be somewhat higher than reported here. Overall, the $\mathrm{O} / \mathrm{C}$ and $\mathrm{H} / \mathrm{C}$ ratios of $\mathrm{CHO}$ compounds in the cloud water samples are within the wide range of the previously reported values, but are closer to those of aerosol water-soluble organic carbon than rainwater. This is probably related to the different extents of aqueous processing and temperature in supercooled and precipitating clouds.

Another measure of molecular unsaturation is the DBE, which indicates the number of double bonds and rings in a molecular structure (Eq. 3). A wide range of DBE values (019) was observed among the cloud water $\mathrm{CHO}$ compounds with a clear trend of increasing DBE values with increasing carbon content $\left(\mathrm{C}_{3}-\mathrm{C}_{36}\right)$ (Fig. $3 b$ ). In both samples, the majority ( $>90 \%$ ) of the compounds have DBE values $\leq 10$ and the high-relative-abundance compounds have DBE values within the range of 2-7. Overall, the average DBE values for CW1 and CW2 CHO compounds are $6.4( \pm 3.6)$ and 6.4 $( \pm 3.2)$, similar to that of $\mathrm{CHO}$ compounds from other studies. Average DBE values for CHO compounds of 5.6 and 6.4 were reported by Lin et al. (2012a) and Mazzoleni et al. (2012) for ambient aerosol; Mazzoleni et al. (2010) reported an average DBE value for $\mathrm{CHO}$ compounds of 5.3 for low-molecular-weight fog water AOM; and Putman et al. (2012) reported an average DBE value for CHO compounds of 7.0 for chamber-generated $\alpha$-pinene ozonolysis SOA. Interestingly, several CHO compounds with high DBE values (i.e., 14-19) were observed and are located in the aromatic region $(\mathrm{O} / \mathrm{C}<0.3$ and $\mathrm{H} / \mathrm{C}<1.0)$ of the van Krevelen diagram (Fig. 3a). Generally, these aromatic compounds are within the mass range of 300-400 Da and have < 6 O atoms. The relative abundances of the compounds with respect to carbon are also illustrated in Fig. 3b. The higher intensity compounds are compounds with $\mathrm{C}_{5}-\mathrm{C}_{25}$. Among these compounds, the highest relative abundances are $\sim \mathrm{C}_{10}$, followed by $\sim \mathrm{C}_{15}$. There is also a relatively high-intensity spot $\sim \mathrm{C}_{20}$ in the $\mathrm{CW} 1$ sample. These high-relative-abundance compounds at $\mathrm{C}_{10}, \mathrm{C}_{15}$, and $\mathrm{C}_{20}$ indicate terpene characteristics in the cloud water CHO compounds (Claeys et al., 2013).

To evaluate the oxygen content, the cloud water $\mathrm{CHO}$ compounds were separated into subclasses based on the number of oxygen atoms $\left(\mathrm{O}_{\#}\right)$ in the molecular formulas, labeled as $\mathrm{O}_{1}, \mathrm{O}_{2}$, and so on. The total relative abundances for each of the subclasses are shown in Fig. 3c. Overall, cloud water $\mathrm{CHO}$ compounds range from $\mathrm{O}_{2}$ to $\mathrm{O}_{22}$, with the majority of compounds in the range of $\mathrm{O}_{2}$ to $\mathrm{O}_{15}$. These subclasses with variable oxygen numbers may reflect multiple and/or various functional groups like hydroxyl, ether, peroxyl, carbonyl, carboxyl, or ester. Interestingly, the highest relative abundances were observed for the $\mathrm{O}_{5}, \mathrm{O}_{7}$, and $\mathrm{O}_{10}$ subclasses. The $\mathrm{O}_{10}$ subclass contains the highest number of CHO compounds ( $\sim 130$ molecular formulas), while the highest relative abundance $\mathrm{CHO}$ compounds were observed in the $\mathrm{O}_{5}$ and $\mathrm{O}_{7}$ subclasses. Examples of the highrelative-abundance $\mathrm{CHO}$ compounds detected in both samples include $\mathrm{C}_{10} \mathrm{H}_{18} \mathrm{O}_{5}, \mathrm{C}_{11} \mathrm{H}_{18} \mathrm{O}_{5}, \mathrm{C}_{10} \mathrm{H}_{14} \mathrm{O}_{7}, \mathrm{C}_{11} \mathrm{H}_{16} \mathrm{O}_{7}$, $\mathrm{C}_{12} \mathrm{H}_{18} \mathrm{O}_{7}, \mathrm{C}_{13} \mathrm{H}_{20} \mathrm{O}_{7}$, and $\mathrm{C}_{14} \mathrm{H}_{22} \mathrm{O}_{7}$. These high-relativeabundance compounds have DBE values of 2, 3, and 4. Interestingly, no formulas in the $\mathrm{O}_{16}$ and $\mathrm{O}_{17}$ classes were observed, but there are several compounds in the higher subclasses $\left(\mathrm{O}_{18}-\mathrm{O}_{22}\right)$. These high oxygen numbers correspond to compounds with $\mathrm{O} / \mathrm{C}$ ratios $>1.0$ in the van Krevelen diagram.

The reconstructed mass spectra of the cloud water $\mathrm{CHO}$ compounds have similar characteristics to laboratorygenerated SOA samples. Three groups of high abundance anions were observed; they include $\mathrm{m} / \mathrm{z} \quad 200-350, \mathrm{~m} / \mathrm{z}$ 350-500, and $m / z$ 500-650 (Fig. 4). Similar clusters of high-relative-abundance anions (sometimes referred to as "oligomers" or monoterpene accretion products in SOA 

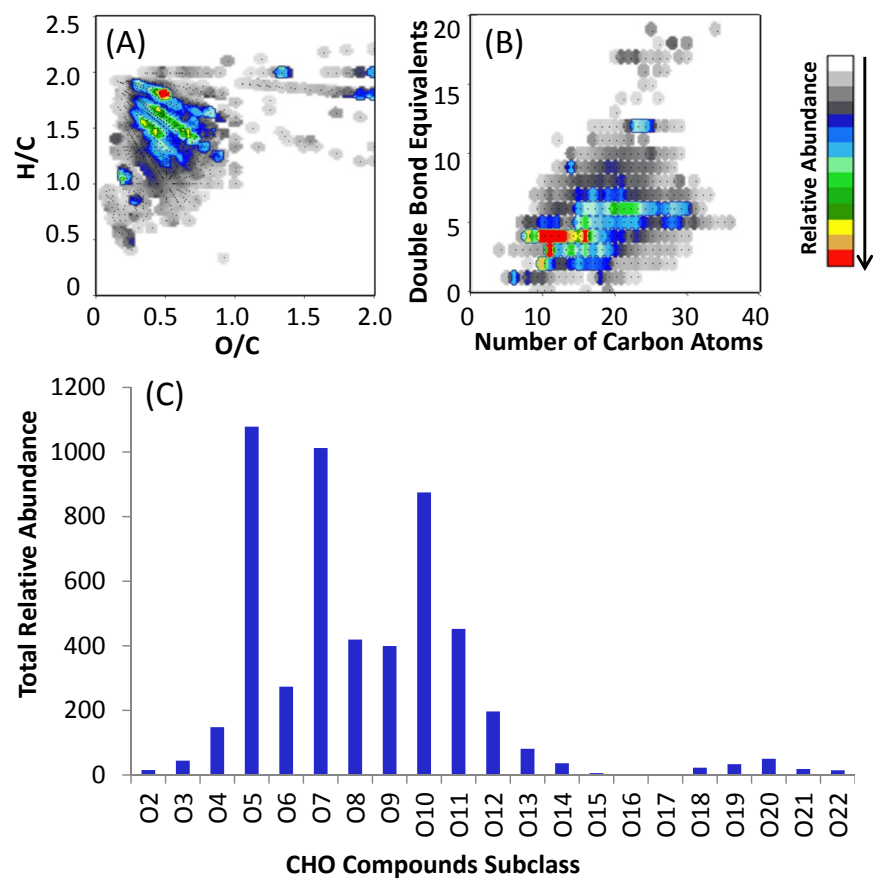

Fig. 3. Isoabundance van Krevelen diagram for CW1 CHO compounds (a). Isoabundance plot of double bond equivalents (DBE) vs. number of carbon atoms in molecular formulas for $\mathrm{CW} 1 \mathrm{CHO}$ compounds (b). Total relative abundance (RA) of each subclass for CW1 CHO compounds (c). The corresponding figures for CW2 CHO compounds are shown in Fig. S4.

samples) have been observed in SOA samples and have decreasing ion intensities with increasing molecular weight (Reinhardt et al., 2007; Bateman et al., 2011; Kundu et al., 2012; Putman et al., 2012). Also the average O/C and H/C ratios of the cloud water $\mathrm{CHO}$ compounds are consistent with those determined for biogenic SOA samples (Bateman et al., 2009, 2010; Putman et al., 2012). In addition, there are several "hot spots" at $\mathrm{C}_{10}, \mathrm{C}_{15}$, and $\mathrm{C}_{20}$ in the isoabundance DBE plots (Fig. 3b) representing the high-relative-abundance compounds. The DBE values and the carbon numbers of the high-relative-abundance compounds reflect monoterpene and sesquiterpene characteristics (Putman et al., 2012). To further explore the SOA composition similarities, the cloud water $\mathrm{CHO}$ molecular formulas were compared to the $\mathrm{CHO}$ molecular formulas assigned to several laboratory-generated biogenic SOA mass spectra. The biogenic SOA samples used in the comparison include $\alpha$-pinene ozonolysis SOA, $\beta$-pinene ozonolysis SOA, d-limonene ozonolysis SOA, and $\beta$-caryophyllene ozonolysis SOA, all of which were generated under dark conditions without an $\mathrm{OH}$ scavenger (e.g., Kundu et al., 2012; Dalbec et al., 2013). Of the CW1 and CW2 CHO molecular formulas, 58 and $64 \%$, were identical to those in the biogenic SOA samples (Fig. 4). Furthermore, most of these common molecular formulas are high-intensity anions in the cloud water samples. Overall, the three groups of anions assigned as $\mathrm{CHO}$ compounds in the reconstructed mass spectra are less distinct than those in the SOA mass spectra. This reflects the more complex conditions for ambi- ent aerosols and clouds than laboratory experimental conditions. Some of the differences include the presence of biogenic SOA from unevaluated precursors, aqueous-phase reactions that alter the composition, and compounds from other sources, etc. Despite the differences between ambient conditions and those of laboratory experiments, we observed highly similar characteristics in the $\mathrm{CHO}$ molecular formulas of cloud water and biogenic SOA. This suggests that a high percentage of the cloud condensation nuclei in the Rocky Mountain region during the cloud sampling study contain biogenic SOA components. Similarly, Sun et al. (2011), using aerosol mass spectrometry, found $\sim 90 \%$ of the aerosol water-soluble organic carbon at a rural site (Centreville, Alabama) in the summer are biogenic related. The fraction decreased in the winter, but still comprised $\sim 50 \%$ of the total water-soluble organic carbon.

In addition to biogenic SOA, the $\mathrm{CHO}$ composition of the clouds appears to be affected by residential wood combustion. Guaiacols and syringols (also known as methoxyphenols) are commonly found in biomass combustion emissions and are from the pyrolysis of wood lignin (Hawthorne et al., 1992; Mazzoleni et al., 2007). Methoxyphenols have been shown by Sun et al. (2010) to contribute to aqueous SOA and have been observed in ambient foggy atmospheres (Sagebiel and Seiber, 1993). Two of the molecular formulas considered to be markers of syringol and guaiacol aqueous-phase reactions in the Sun et al. (2010) experiments were observed in the cloud water samples. They are $\mathrm{C}_{16} \mathrm{H}_{18} \mathrm{O}_{6}(\mathrm{RA}=7 \%$ 
in both samples) and $\mathrm{C}_{14} \mathrm{H}_{14} \mathrm{O}_{4}(\mathrm{RA}=2.7 \%$ in $\mathrm{CW} 1$ and $4 \%$ in CW2). As described, molecular formulas assigned to exact mass measurements using ultrahigh-resolution FTICR mass spectrometry provide valuable insights regarding the chemical structure (e.g., elemental ratios and DBE). A large fraction of the high-relative-abundance $\mathrm{O}_{5}$ (50 out of 79 formulas in CW1, 39 out of 63 formulas in CW2) and $\mathrm{O}_{7}$ (68 out of 74 formulas in CW1, 74 out of 77 formulas in CW2) $\mathrm{CHO}$ compounds have DBE values $\geq 4$. This combination is consistent with methoxyphenol-derived structures since there is both enough oxygen for the functional groups of $-\mathrm{OCH}_{3}$ and $-\mathrm{OH}$ and enough DBE for the benzene ring. Samy et al. (2010) analyzed aerosol and supercooled cloud water samples collected at the SPL. They found abundant concentrations of methoxyphenols in both the aerosols and the cloud samples, which suggested a strong biomass burning chemical signature. The emissions likely arise from nearby residential wood combustion in Yampa Valley to the west of the SPL. In this study, the back-trajectory analysis indicates the air was coming from west and northwest during the sampling periods (Figs. S2 and S3) thus it was likely influenced by residential activities in Yampa Valley. Similarly, Collett et al. (2008) also reported fog processing of carbonaceous particles from wood smoke. Residential wood combustion may contribute to the observed biogenic SOA in the cloud samples. It is known that terpenoid emissions from living plants are highly correlated to ambient temperature (Kesselmeier and Staudt, 1999), and thus biogenic SOA is generally not expected to be significant during the winter time periods. However, trees have a large storage reservoir of the monoterpenes compared to their emission rates (Lerdau et al., 1994; Amin et al., 2012). Thus, the stored monoterpenes may be released during residential wood combustion for SOA formation.

\subsection{Compounds containing only $\mathrm{C}, \mathrm{H}, \mathrm{N}$, and $\mathrm{O}$}

A wide range of elemental ratios was observed for the $\mathrm{CHNO}$ compounds (Fig. 5a). In contrast to the elemental ratios of the $\mathrm{CHO}$ compounds, where the majority of the compounds have $\mathrm{O} / \mathrm{C}<1.0$, many of the $\mathrm{CHNO}$ compounds have $\mathrm{O} / \mathrm{C}$ $>1.0$; they also have some of the highest relative abundances of the CHNO group. Most of these CHNO compounds with high $\mathrm{O} / \mathrm{C}$ ratios also have high $\mathrm{H} / \mathrm{C}$ ratios ( > 1.2), suggesting that the compounds are both highly saturated and oxygenated. For example, the molecular formulas of the homologous series $\mathrm{C}_{5} \mathrm{H}_{10} \mathrm{~N}_{2} \mathrm{O}_{9}\left(\mathrm{CH}_{2}\right)_{1-3}$ with high relative abundances show these characteristics. Also, there are a large number $(\sim 50 \%)$ of CHNO molecular formulas with $\mathrm{O} / \mathrm{C}$ $<0.7$. In general, these compounds have a relatively low relative abundance and have a large range of $\mathrm{H} / \mathrm{C}$ ratios $(0.3$ to 2.2). Overall, the average $\mathrm{O} / \mathrm{C}$ ratios of the $\mathrm{CHNO}$ compounds in CW1 and CW2 are $0.72( \pm 0.34)$ and $0.73( \pm 0.31)$, respectively. The average $\mathrm{H} / \mathrm{C}$ ratios for the $\mathrm{CHNO}$ compounds in CW1 and CW2 are $1.56( \pm 0.29)$ and $1.56( \pm 0.30)$ (Table 1). Previous studies of aerosol WSOC and fog AOM observed overall less oxygenated CHNO compounds, with average $\mathrm{O} / \mathrm{C}$ ratios typically $<0.5$ (Wozniak et al., 2008; Mazzoleni et al., 2010; Schmitt-Kopplin et al., 2010). However in the study of rainwater AOM by Altieri et al. (2009b), several CHNO compounds were identified with high $\mathrm{O} / \mathrm{C}$ ratios (some even higher than 2.0). They reported an average $\mathrm{O} / \mathrm{C}$ ratio of $1.6( \pm 1.4)$ for the $\mathrm{CHNO}$ compounds. The presence of highly oxygenated $\mathrm{CHNO}$ compounds $(\mathrm{O} / \mathrm{C}>1.0)$ appears to be related to aqueous-phase reactions in cloud and rainwater droplets.

Consistent with the $\mathrm{H} / \mathrm{C}$ elemental ratios, the majority of the CHNO compounds have DBE values $\leq 10$ (Fig. 5b). Similar to the $\mathrm{CHO}$ compounds, the number of carbon atoms in the formulas range from $\mathrm{C}_{2}$ to $\mathrm{C}_{35}$ and the DBE values increase with the number of carbon atoms. The high-intensity CHNO compounds with $\mathrm{C}_{2}-\mathrm{C}_{20}$ have $\mathrm{DBE}$ values $\leq 6$. The most abundant compounds are those with $\mathrm{C}_{11}$ and low DBE values (2-4). These values indicate that most of the CHNO compounds are relatively saturated, especially those with higher relative abundances. Only a small fraction $(\sim 3 \%)$ of the CHNO compounds have high DBE values from 11 to 19. As illustrated in Fig. 5b, the high-DBE CHNO compounds have low relative abundances. Overall, the average DBE values are $5.6( \pm 2.6)$ and $5.6( \pm 2.8)$ for $\mathrm{CW} 1$ and $\mathrm{CW} 2 \mathrm{CHNO}$ compounds. Therefore the cloud water $\mathrm{CHNO}$ compounds are mostly saturated, with a few exceptions.

Cloud water $\mathrm{CHNO}$ compounds contain 1-4 nitrogen atoms $\left(\mathrm{N}_{1}-\mathrm{N}_{4}\right)$ per molecular formula. The compounds with $\mathrm{N}_{1}$ represented $\sim 43 \%$ of the CHNO compounds in both samples, followed by compounds containing $\mathrm{N}_{2}(\sim 29 \%)$, $\mathrm{N}_{3}(\sim 21 \%)$, and $\mathrm{N}_{4}(\sim 7 \%)$ in both samples. To further examine the $\mathrm{N}$ in the molecular formulas, CHNO subclasses were defined by the numbers of nitrogen and oxygen in the molecular formulas; they include $\mathrm{NO}_{3-23}, \mathrm{~N}_{2} \mathrm{O}_{3-18}$, $\mathrm{N}_{3} \mathrm{O}_{2-16}$, and $\mathrm{N}_{4} \mathrm{O}_{1-19}$. The total relative abundance for the compounds contained within the subclasses is shown in Fig. 5c. Interestingly, the plot clearly indicates that the highrelative-abundance $\mathrm{CHNO}$ compounds are in the subclasses of $\mathrm{NO}_{6-14}, \mathrm{~N}_{2} \mathrm{O}_{8-16}$, and $\mathrm{N}_{3} \mathrm{O}_{11-16}$. The compounds in high-relative-abundance subclasses correspond to the hot spots in the upper right region of the isoabundance van Krevelen diagram $(\mathrm{O} / \mathrm{C}>0.7, \mathrm{H} / \mathrm{C}>1.5$, Fig. 5a). All the high-relative-abundance $\mathrm{CHNO}$ subclasses are rich in oxygen with respect to nitrogen. Almost all of these classes show an oxygen-to-nitrogen ratio $(\mathrm{O} / \mathrm{N}) \geq 3$. Thus, the $\mathrm{CHNO}$ compounds appear to contain a large number of organonitrates (with the functional group of $-\mathrm{NO}_{3}$ ); however $\mathrm{CHNO}$ compounds are not exclusively organonitrates since multifunctional compounds are anticipated. For example a study using an ultrahigh-resolution "tandem mass spectrometry" technique reported only $63 \% \mathrm{HNO}_{3}$ losses from CHNO and CHNOS compounds in fog water samples (LeClair et al., 2012).

Organonitrates or nitrooxy organosulfates have been observed in several AOM samples (Allen et al., 1994; Nielsen 


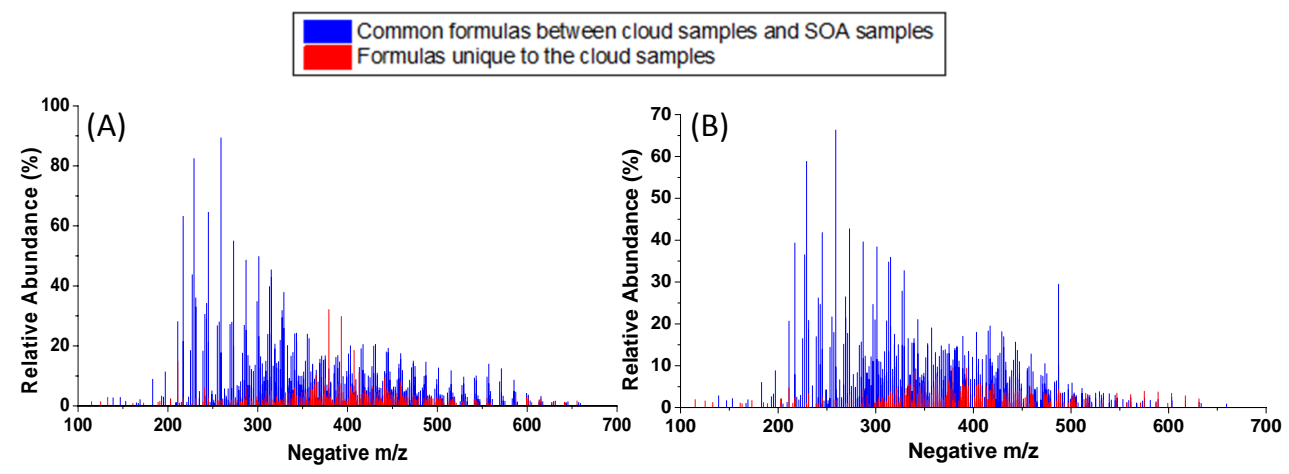

Fig. 4. Reconstructed mass spectra of the CHO compounds in CW1 (a) and CW2 (b). Blue peaks show the common formulas between the cloud water samples and biogenic SOA samples (combined data of ozonolysis of $\alpha$-pinene, $\beta$-pinene, d-limonene and $\beta$-caryophyllene); red peaks show the formulas unique to cloud water samples.
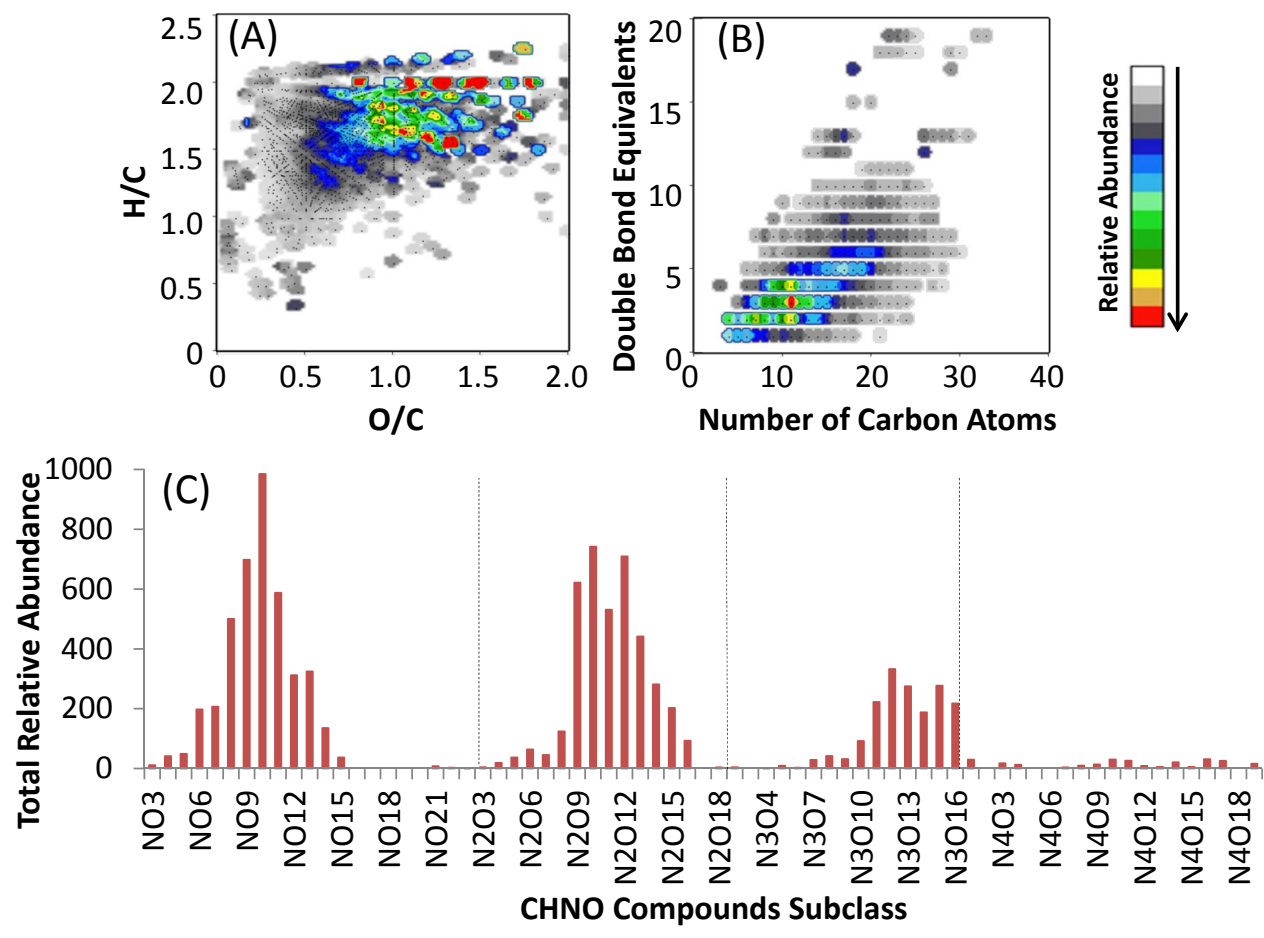

Fig. 5. Isoabundance van Krevelen diagram for CW1 CHNO compounds (a). Isoabundance plot of DBE vs. number of carbon atoms in molecular formulas for CW1 CHNO compounds (b). Total relative abundance (RA) of each subclass for CW1 CHNO compounds; the dashed lines separate the subclasses by number of nitrogen atoms contained in the formulas (c). The corresponding figures for CW2 $\mathrm{CHNO}$ compounds are shown in Fig. S5.

et al., 1998; Zhang and Anastasio, 2001; Garnes and Allen, 2002; Herckes et al., 2007; Reemtsma et al., 2006; Surratt et al., 2006; Altieri et al., 2008; Bruns et al., 2010; Fry et al., 2013). The organonitrates or nitrooxy organosulfates observed in the clouds may be from dissolution of $\mathrm{CCN}$ aerosol, gas organic compounds containing nitro- or nitrate groups partitioned to the droplets (Lüttke and Levsen, 1997; Lüttke et al., 1997), or aqueous formation within the cloud droplets. Alkyl nitrates have relatively high vapor pressures, so they are not expected to readily partition to the particle phase. In a study by Nielson et al. (1998), only alkyl nitrates with $>18$ carbon atoms can contribute to the particulate organic nitrogen mass at $20^{\circ} \mathrm{C}$. However hydroxyl or carboxylic acid functional groups lower the vapor pressure (Arp and Goss, 2009), allowing the multifunctional organonitrates with less carbon atoms to partition to the particle phase. This coupled with the low temperatures during the sampling period $\left(\sim-10^{\circ} \mathrm{C}\right)$ enhances the significance of organonitrates in the 
condensed phase. Therefore it is highly possible that a considerable number of organonitrates are present in the supercooled cloud droplet samples. Similarly, nitrate esters were also observed in fog water (Herckes et al., 2007).

As mentioned $\sim 50 \%$ of the $\mathrm{CHNO}$ compounds have $\mathrm{O} / \mathrm{C}$ ratios $<0.7$ (Fig. 5a). These low $\mathrm{O} / \mathrm{C}$ ratios are similar to those reported by Schmitt-Kopplin et al. (2010) for a biomass burning aerosol sample. In that study, almost all the identified nitrogen-containing species had $\mathrm{O} / \mathrm{C}$ ratios less than 0.7 . The lower oxygen content suggests the presence of reduced nitrogen compounds. Wood combustion emissions are known to emit reduced nitrogen compounds. In a study by Laskin et al. (2009) a substantial fraction of Nheterocyclic alkaloid compounds were observed in biomass burning aerosols. In another study by Bateman et al. (2010), an $\mathrm{O} / \mathrm{C}$ ratio of 0.19 was reported for combustion of dried pine needles and sticks. Thus, the residential wood combustion in the vicinity of the SPL is a likely contributor to the reduced nitrogen-containing species observed in the cloud water samples. However this does not exclude the possibility of aqueous-phase reactions resulting in nitrogencontaining species like those formed by aqueous-phase reactions of glyoxal (Galloway et al., 2009; Shapiro et al., 2009) or methylglyoxal (De Haan et al., 2010; Sareen et al., $2010)$ with $\left(\mathrm{NH}_{4}\right)_{2} \mathrm{SO}_{4} / \mathrm{NH}_{4} \mathrm{NO}_{3}$. Reaction products such as amine, imine, or imidazole provide another likely source of the reduced nitrogen compounds in the cloud water samples. Alkyl amines have also been detected in ambient aerosols (Gilardoni et al., 2009) and fog water (Zhang and Anastasio, 2001; Herckes et al., 2007). Regardless of their origin, reduced nitrogen functional groups can be oxidized in the cloud droplets to form oxidized functional groups as indicated by the high $\mathrm{O} / \mathrm{C}$ ratios of products from aqueous-phase reactions (Lim et al., 2010; Ervens et al., 2011).

\subsection{Compounds containing only $\mathrm{C}, \mathrm{H}, \mathrm{O}$, and $\mathrm{S}$ and $\mathrm{C}, \mathrm{H}, \mathrm{N}, \mathrm{O}$, and $\mathrm{S}$}

A wide range of elemental ratios is shown in Fig. 6a for the CHOS compounds and Fig. 7a for the CHNOS compounds. Similar to the $\mathrm{CHO}$ (Fig. 3a) and CHNO compounds (Fig. 5a), the elemental ratios align into several straight lines indicating $\mathrm{CH}_{2}$ homologous series. However instead of one large group in the isoabundance van Krevelen diagrams, subgroups of the CHOS and CHNOS compounds in the isoabundance van Krevelen diagrams are depicted. Some obvious differences in the isoabundance van Krevelen diagrams of the CHOS and CHNOS compounds compared to those of the $\mathrm{CHO}$ and $\mathrm{CHNO}$ compounds were observed (Figs. 6a and 7a). First, the presence of a high number of highly unsaturated CHOS and CHNOS compounds was observed. Second, we observed a wider overall range of elemental ratios with variable relative abundances. These compound properties are explored in more detail in the following paragraphs.
Four subgroups of CHOS molecular formulas with varied unsaturations or DBE values were observed (Fig. 6). The CHOS compounds in subgroup 1 with $\mathrm{H} / \mathrm{C}>2$ are highly saturated with DBE values of 0 or 1 (Fig. 6b). These compounds belong to the subclasses of $\mathrm{O}_{4} \mathrm{~S}, \mathrm{O}_{5} \mathrm{~S}$, and $\mathrm{O}_{6} \mathrm{~S}$ (Fig. 6c). Subgroup 2 CHOS compounds are less saturated and contain the subclasses of $\mathrm{O}_{7-12} \mathrm{~S}$ with relatively low DBE values (mostly 3 or 4 ). The CHOS compounds in subgroup 3 are highly oxygenated with the subclasses of $\mathrm{O}_{15-18} \mathrm{~S}$. They are less saturated than those in subgroup 2 with DBE values ranging from 7 to 9 . Most of the subgroup 3 molecular formulas have relatively high molecular weight, typically $>400 \mathrm{Da}$. Thus from subgroups 1 to 3 , the DBE values increase (from 0 to 9 ) with the increase of oxygen content in the molecular formulas $\left(\mathrm{O}_{4}\right.$ to $\left.\mathrm{O}_{18}\right)$. The CHOS compounds in subgroup 4 are the most unsaturated of the CHOS compounds. The DBE values of these molecular formulas range from 8 to 19 , suggesting aromatic moieties. Unlike the compounds in the previous subgroups, these have low $\mathrm{O} / \mathrm{C}$ ratios $(<0.4)$. The subclasses of $\mathrm{O}_{1-3} \mathrm{~S}$ in this group contain too little oxygen to contain organic sulfate functional groups. Overall around $1 / 3$ of the detected CHOS compounds are in subgroup 4 which appears to be reduced sulfur species.

Similarly, the CHNOS compounds have similar elemental ranges (Fig. 7a). The number of CHNOS compounds in subgroups 1-3 are less than those of the CHOS compounds and the subgroup 4 CHNOS compounds are clearly dominant among the CHNOS compounds. Overall, a total of $75 \%$ of the CHNOS compounds are in subgroup 4 and $25 \%$ in subgroups 1-3. The CHNOS compounds in subgroups 1-3 have DBE values ranging from 1 to 8 (Fig. 7b). These compounds contain 1 or 2 nitrogen atoms in the molecular formulas with a high number of oxygen atoms ( $>7$, subclasses $\mathrm{NO}_{7-12,18} \mathrm{~S}$ and $\mathrm{N}_{2} \mathrm{O}_{12-16} \mathrm{~S} ;$ Fig. $7 \mathrm{c}$ ). Based on the oxygen numbers and DBE values, some of the molecular formulas may represent organonitrates, organosulfates, or nitrooxy organosulfates. In contrast, the subgroup 4 CHNOS compounds are highly aromatic, with DBE values from 6 to 19. Most of the CHNOS compounds with 3 or 4 nitrogen atoms in their molecular formulas are in this group, including: $\mathrm{N}_{3} \mathrm{O}_{1-11} \mathrm{~S}$ and $\mathrm{N}_{4} \mathrm{O}_{1-5} \mathrm{~S}$. Furthermore, CHNOS compounds with 1 or 2 nitrogen atoms and a low number of oxygen atoms are in this group, including: $\mathrm{NO}_{2-8} \mathrm{~S}$ and $\mathrm{N}_{2} \mathrm{O}_{2-9} \mathrm{~S}$. Therefore, consistent with the cloud water CHOS compounds, the CHNOS compounds also include characteristics that are either highly oxygenated or highly aromatic. The aromatic S-containing compounds are dominant in number and thus greatly influence the average DBE value for these elemental classes.

Considering the adequate oxygen content and low DBE values (DBE for a sulfate functional group is 0 using Eq. (3)), the S-containing compounds detected in subgroups 1-3 can be organosulfates or nitrooxy-organosulfates. Examples include the several high-relative-abundance, lowmolecular-weight CHOS compounds detected in both samples (200-300 Da): $\mathrm{C}_{12} \mathrm{H}_{26} \mathrm{O}_{4} \mathrm{~S}, \mathrm{C}_{9} \mathrm{H}_{18} \mathrm{O}_{8} \mathrm{~S}, \mathrm{C}_{14} \mathrm{H}_{30} \mathrm{O}_{4} \mathrm{~S}$, 

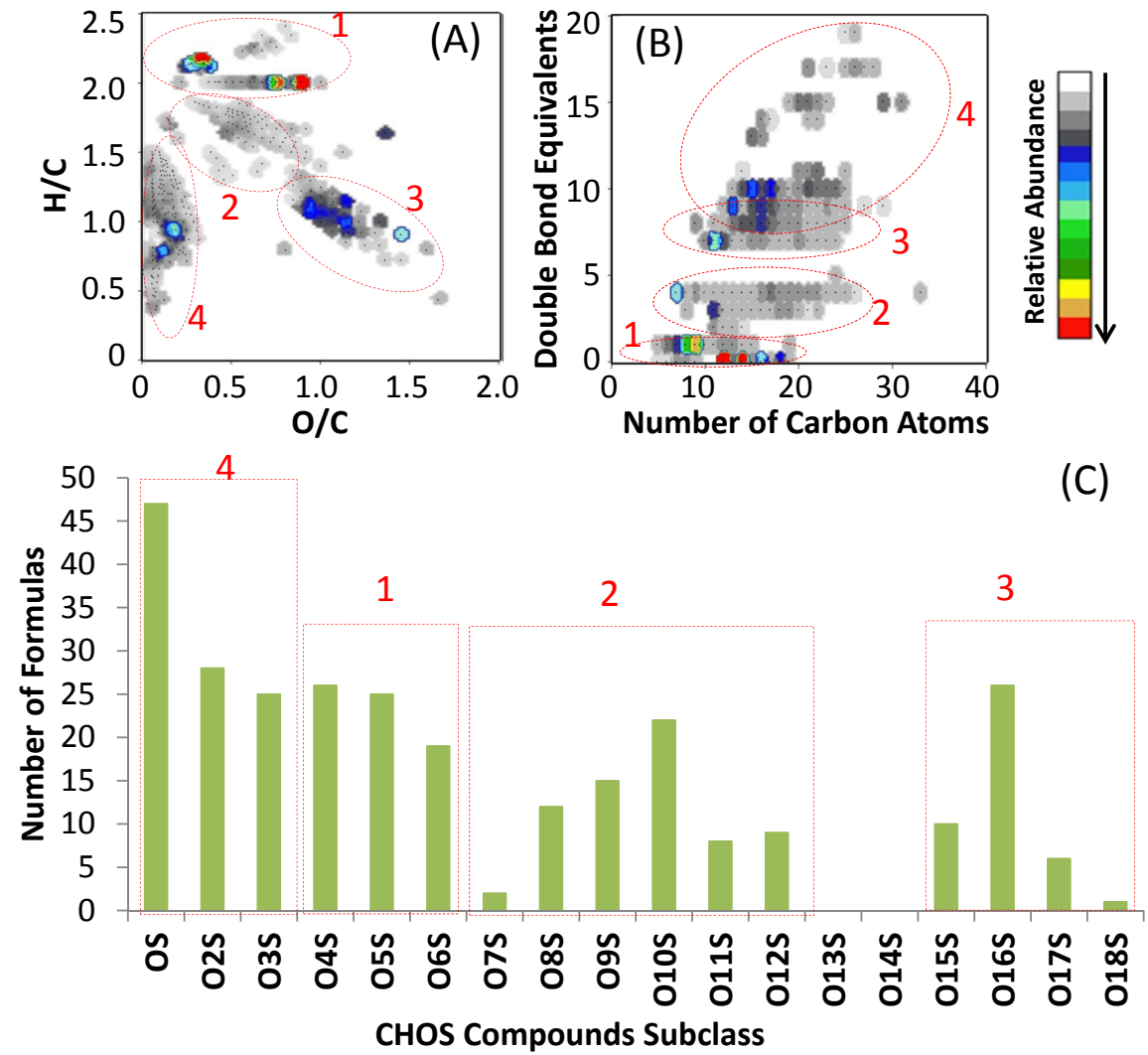

Fig. 6. Isoabundance van Krevelen diagram for CW1 CHOS compounds (a). Isoabundance plot of DBE vs. number of carbon atoms in molecular formulas for CW1 CHOS compounds (b). Number of formulas identified in each of the CW1 CHOS subclasses (c). The red circles and boxes indicate the approximate groupings (1 to 4) of the CW1 CHOS formulas. The corresponding figures for CW2 CHOS compounds are shown in Fig. S6.

and $\mathrm{C}_{8} \mathrm{H}_{16} \mathrm{O}_{6} \mathrm{~S}$. LeClair et al. (2012) also detected these molecular formulas in fog water and used MS/MS to confirm the sulfate group in the structures. Organosulfates have been detected commonly in atmospheric samples (Surratt et al., 2006; Gómez-González et al., 2008; Hatch et al., 2011). In fact, most of the atmospheric S-containing organic compounds reported in the literature are organosulfates or nitrooxy organosulfates. Observations from both chamber simulations (Iinuma et al., 2007; Liggio et al., 2007; Surratt et al., 2007) and field measurements (Surratt et al., 2008; Stone et al., 2012; Pratt et al., 2013) indicate that organosulfates and nitrooxy organosulfates can form in biogenic secondary organic aerosols. The identified organosulfates in biogenic SOA usually have carbon atom numbers similar to their biogenic precursors, e.g., $\sim 5$ or 10 (Surratt et al., 2008). In the cloud water samples, most of the CHOS and CHNOS compounds with less than 12 carbon atoms contain more than 4 oxygen atoms. Considering the cloud water biogenic SOA characterization identified from the cloud water $\mathrm{CHO}$ compounds, these organosulfates and nitrooxy organosulfates compounds (S-containing compounds in subgroups 1-3) may have originated from biogenic pre- cursors. Several high-molecular-weight organosulfate candidates (> 300 Da) with more carbon atoms (16 to 33) were also detected in the cloud water, including: $\mathrm{C}_{17} \mathrm{H}_{18} \mathrm{O}_{16} \mathrm{~S}$, $\mathrm{C}_{18} \mathrm{H}_{38} \mathrm{O}_{6} \mathrm{~S}$, and $\mathrm{C}_{17} \mathrm{H}_{20} \mathrm{O}_{16} \mathrm{~S}$. The high-molecular-weight organosulfates have been observed previously in atmospheric aerosols (Romero and Oehme, 2005; Reemtsma et al., 2006). Mostly AOM organosulfates are secondary reaction products (Hatch et al., 2011). Two formation mechanisms were proposed, including: esterification of hydroxyl groups with sulfuric acid (Liggio et al., 2005; Surratt et al., 2007) and acidcatalyzed reactions of epoxides (Minerath and Elrod, 2009). Both of the pathways require sulfuric acid anions (Surratt et al., 2007; Minerath and Elrod, 2009). Considering the coalfired power plants located to the west of the SPL area, which are emission sources of $\mathrm{SO}_{2}$, and the aqueous-phase processing that may take place within cloud droplets, formation of organosulfates is likely.

Although organosulfates and nitrooxy organosulfates were observed, a dominant number of S-containing compounds contain reduced S (e.g., aromatic S) due to insufficient oxygen content in the molecular formulas (subgroup 4 in Figs. 6 and 7). AOM with reduced $S$ is rarely reported 

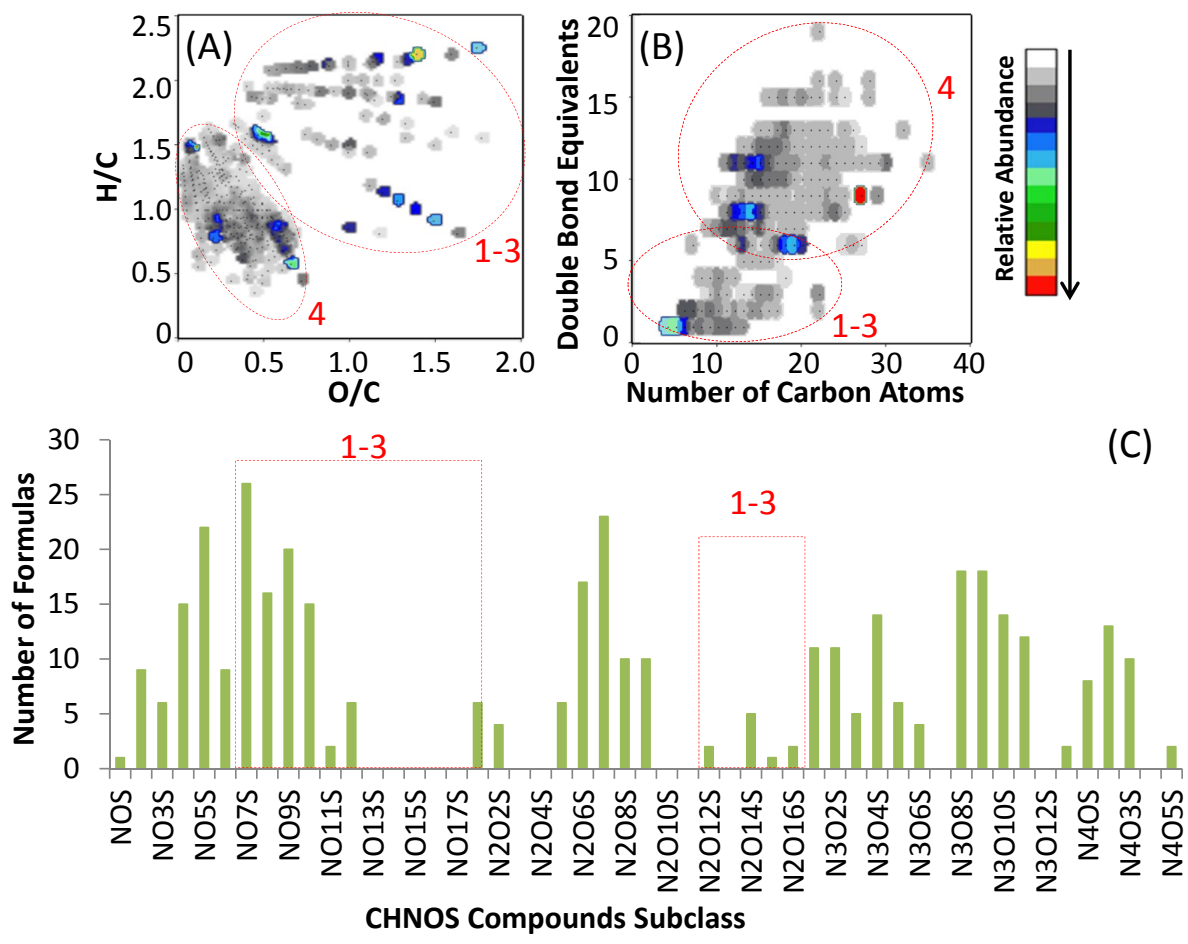

Fig. 7. Isoabundance van Krevelen diagram for CW1 CHNOS compounds (a). Isoabundance plot of DBE vs. number of carbon atoms in molecular formulas for CW1 CHNOS compounds (b). Number of formulas identified in each of CW1 CHNOS subclasses (c). The red circles indicate the approximate groupings ( 1 to 4 ) of the CW1 CHNOS formulas. The bars not boxed in (c) belong to group 4 . The corresponding figures for CW2 CHNOS compounds are shown in Fig. S7.

(Saranjampour, 2012; Kundu et al., 2013). Most of the highDBE, S-containing compounds observed in cloud water have high carbon numbers ( $>10$, Figs. $6 \mathrm{~b}$ and $7 \mathrm{~b}$ ). Instead of being secondary products like the organosulfates, they may be from primary emissions. The diesel fuel used to power snow cats used to groom the ski area at night near the SPL may be a source of reduced $\mathrm{S}$ compounds. Further investigation is needed to determine the origin of the unambiguously identified reduced $\mathrm{S}$ compounds.

\subsection{Cloud water AOM properties}

Overall, the bulk properties of the two cloud water samples are very similar (Table 1). The average $\mathrm{O} / \mathrm{C}$ ratios of the CW1 and CW2 samples are $0.62( \pm 0.37)$ and 0.61 $( \pm 0.34)$ and the average $\mathrm{H} / \mathrm{C}$ ratios are $1.46( \pm 0.36)$ and $1.46( \pm 0.35)$. The average elemental ratios of each compound group with and without relative-abundance-weighting (Eqs. S1 and S2) are summarized in Table 1. The relativeabundance-weighted elemental ratios are very similar in most cases to the unweighted values discussed here. As shown in Table 1 , the $\mathrm{O} / \mathrm{C}$ ratios of the $\mathrm{CHO}$, CHOS, and CHNOS compounds are all approximately 0.5 , but the $\mathrm{O} / \mathrm{C}$ of the CHNO compounds is $\sim 0.7$. Thus the overall elemental ratios are highly influenced by the CHNO compounds given their high number frequency and high relative abundance. Low- molecular-weight organic compounds like formate, acetate, and formaldehyde observed previously in ambient samples (van Pinxteren et al., 2005; Herckes et al., 2007; Collett et al., 2008; Samy et al., 2010) but not here have relatively high $\mathrm{O} / \mathrm{C}$ ratios ( > 1). In general the overall $\mathrm{O} / \mathrm{C}$ ratios observed here are consistent with the $\mathrm{O} / \mathrm{C}$ ratios observed for other aerosol water-soluble organic carbon and AOM samples, but they are at the higher end of the reported range. For example, Aiken et al. (2008) reported $\mathrm{O} / \mathrm{C}$ ratios for various ambient aerosols from 0.16 to 0.76 using aerosol mass spectrometry. Similarly, Lee et al. (2012) estimated O/C ratios of lowvolatility cloud water organics to be between 0.52 and 0.59 . The observed cloud water $\mathrm{O} / \mathrm{C}$ values are higher than Mazzoleni et al. (2010) observed in fog water collected in Fresno, California (0.43), but lower than Altieri et al. (2009b) observed in rainwater collected in New Jersey (0.96). Similar to the $\mathrm{O} / \mathrm{C}$ ratios, the $\mathrm{H} / \mathrm{C}$ ratios of $\mathrm{CHNO}$ compounds are higher than those of the CHO, CHOS, and CHNOS compounds, so the overall $\mathrm{H} / \mathrm{C}$ values are mainly driven by the high number and relative abundances of CHNO compounds. The observed $\mathrm{H} / \mathrm{C}$ ratios for the cloud water are also within the range of reported values for aerosol water-soluble organic carbon and AOM samples. Aiken et al. (2008) reported H/C ratios for ambient aerosols from 1.41 to 1.89 . A similar range of $\mathrm{H} / \mathrm{C}$ values was observed in fog and rainwater samples. 
Average DBE values and relative-abundance-weighted average DBE values (Eq. S3) of each compound group are listed in Table 1. The average DBE values of the CW1 and CW2 samples are $6.30( \pm 3.37)$ and $6.29( \pm 3.29)$. Again despite the aromatic compounds identified in the $\mathrm{CHO}$, CHOS, and CHNOS groups, the high number of saturated CHNO compounds lowers the overall average DBE values. The relative-abundance-weighted average values of the samples are even lower than the unweighted average DBE values due to the influence of high-relative-abundance saturated CHNO compounds. Similarly, the relative-abundanceweighted DBE value for the summer aerosol water-soluble organic carbon at the SPL was observed to be $5.35( \pm 0.05)$ (Mazzoleni et al., 2012). In general, the DBE values for the cloud water AOM are consistent with a strong biogenic influence (e.g., oxidation products of terpenes and methoxyphenols) and are comparable to other aerosol water-soluble organic carbon and AOM samples.

The average and relative-abundance-weighted organic mass-to-organic carbon ratios (OM/OC) for the samples and each of the compound groups were also evaluated (Table 1). Consistent with previous studies (Altieri et al., 2009b; Mazzoleni et al., 2012), we define OM/OC as the measured mass divided by the calculated mass of $\mathrm{C}$ in the assigned formulas. Overall, the OM/OC ratios for the clouds were $\sim 2.1$. As expected, the compound groups with heteroatoms ( $\mathrm{N}$ and $\mathrm{S}$ ) have higher $\mathrm{OM} / \mathrm{OC}$ ratios than the $\mathrm{CHO}$ compound group. The observed OM / OC ratios for the clouds are slightly higher than those for the ambient aerosols (Aiken et al., 2008; Mazzoleni et al., 2012), reflecting a higher oxidized characteristic and the importance of $\mathrm{N}$ - and S-containing compounds identified in clouds.

Although the overall bulk properties for the two cloud water samples are quite similar, detectable compositional differences between the two samples were observed within the $\mathrm{N}$-containing compounds. The reconstructed difference mass spectrum between the $\mathrm{CW} 1$ and $\mathrm{CW} 2 \mathrm{CHNO}$ compounds (Fig. 8) shows several unique peaks with high relative abundance in CW1 in the range of $m / z 250-350$, while those in CW2 are within the range of $m / z 350-450$. The unique highrelative-abundance CHNO compounds in CW1 are mostly saturated compounds with low DBE values (2 and 4). Some examples of these compounds are the homologs of $\mathrm{N}_{2} \mathrm{O}_{10}$ with DBE values of $2\left(\mathrm{C}_{4} \mathrm{H}_{8}\left(\mathrm{CH}_{2}\right)_{1-5} \mathrm{~N}_{2} \mathrm{O}_{10}\right)$, and homologs of $\mathrm{N}_{2} \mathrm{O}_{9}$ with DBE values of $4\left(\mathrm{C}_{8} \mathrm{H}_{12}\left(\mathrm{CH}_{2}\right)_{1-3} \mathrm{~N}_{2} \mathrm{O}_{9}\right)$. However, the unique high-relative-abundance $\mathrm{CHNO}$ compounds in CW2 contain one nitrogen atom instead of two. Some example compounds are homologs of $\mathrm{NO}_{10}$ with DBE values of 3,5 , or 7 , and homologs of $\mathrm{NO}_{11}$ with DBE values of $4,5,6$, or 8 . The average $\mathrm{N} / \mathrm{C}$ ratios for the unique CHNO compounds are 0.15 in CW1 and 0.13 in CW2. Similarly, the average $\mathrm{N} / \mathrm{C}$ for the unique CHNOS compounds in $\mathrm{CW} 1$ is higher than in CW2 (0.12 versus 0.10$)$. These observations may be the result of nighttime $\mathrm{NO}_{\mathrm{x}}$ chemistry (Iinuma et al., 2007 ; Fry et al., 2013). At night, nitrate radical $\left(\mathrm{NO}_{3}\right)$ is pro- duced from the reaction of $\mathrm{O}_{3}$ and $\mathrm{NO}_{2}$, which can react with organics $\left(\mathrm{RO}_{2}\right)$ to produce organonitrates $\mathrm{RONO}_{2}(\mathrm{Kroll}$ and Seinfeld, 2008). As discussed in Section 3.3, organonitrates observed in the clouds may be from the CCN particulate phase, the gas phase, or formed within the aqueous phase. The $\mathrm{NO}_{\mathrm{x}}$ chemistry can be involved in all these pathways at night. For example, more organonitrates would be produced in the gas phase and partitioned to the aerosols. Also, it has been shown that nitrate radical can transfer from the atmospheric gas phase to the aqueous phase and is the main source of nitrate radical in aqueous phase (Herrmann et al., 2010). Oxidation of reduced N-containing compounds or nitrate radical oxidation of $\mathrm{CHO}$ or CHOS compounds in the aqueous phase may occur (Perraud et al., 2010). Since part of the CW1 composite was collected at night, it is reasonable to observe more $\mathrm{N}$-containing compounds with higher nitrogen content in the molecular formulas from nighttime $\mathrm{NO}_{\mathrm{x}}$ chemical pathways in CW1 than in CW2.

\section{Conclusions}

Approximately 3000 monoisotopic molecular formulas were assigned to each of the two supercooled cloud water samples collected at Storm Peak Laboratory. An overall complex organic composition with $\mathrm{N}, \mathrm{O}$, and $\mathrm{S}$, as well as a wide range of DBE values similar to other ambient aerosol water-soluble organic carbon and aqueous AOM samples, was observed. CHO, CHNO, CHOS, and CHNOS compounds with molecular weights up to $700 \mathrm{Da}$ were observed in the cloud samples. Approximately $70 \%$ of the identified molecular formulas were observed in the mass range of 300 to $500 \mathrm{Da}$. Unique to this observation, the CHNO compounds had the highest number frequency and relative abundances. The average elemental ratios $(\mathrm{O} / \mathrm{C}=0.6$ and $\mathrm{H} / \mathrm{C}=1.5$ ) and DBE values (6.3) were largely influenced by the highly oxygenated $\mathrm{CHNO}$ compounds in the clouds and were slightly higher than the aerosol water-soluble organic carbon collected in the summer at this site. Consistent with the summer aerosol water-soluble organic carbon composition, the majority of the cloud water $\mathrm{CHO}$ compounds matched $\mathrm{CHO}$ compounds assigned to chamber-generated biogenic SOA. Furthermore, the organosulfates observed in the clouds suggest biogenic contributions to the cloud water AOM. Biomass stored terpenes are likely released during residential wood combustion, yielding significant biogenic SOA-like composition. Combustion products also influence the cloud water AOM composition as evidenced by the high number ( $\sim 1500$ unique formulas) of nitrogen-containing compounds. Approximately one-third of the CHOS and approximately three-quarters of the CHNOS compounds were identified as reduced S-containing compounds. They might be from diesel fuel combustion or power plant emissions, but further investigation is needed to determine their origin. More nitrogen atoms were associated with the high 


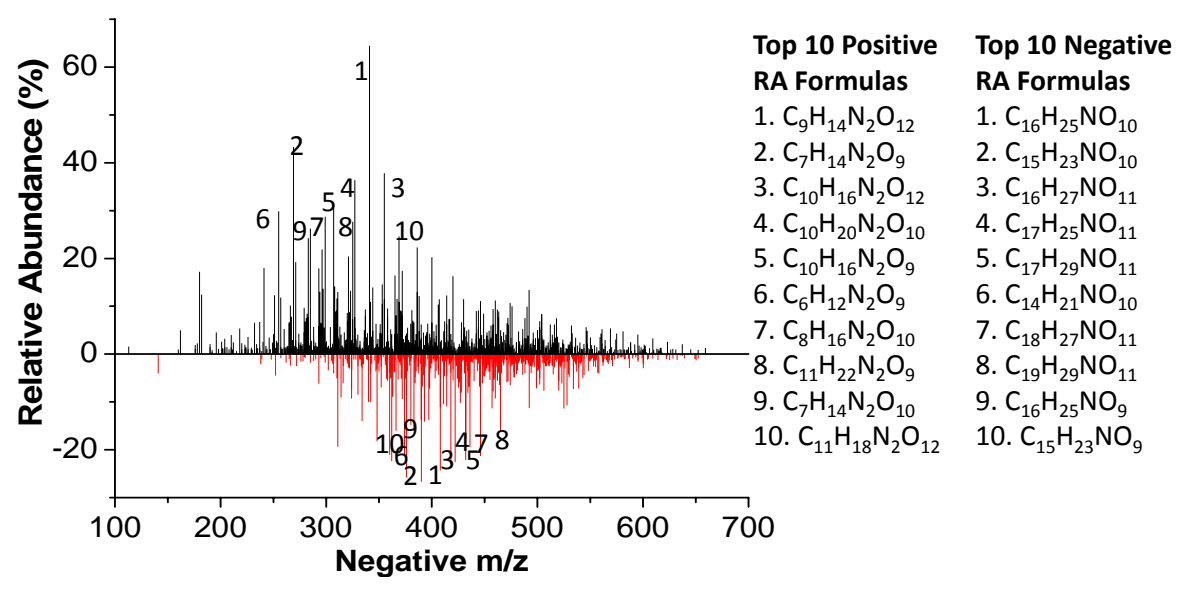

Fig. 8. Difference mass spectra of CHNO compounds between CW1 and CW2. Positive relative abundance (black peaks) means the compound has higher relative abundance in $\mathrm{CW} 1$; negative relative abundance (red peaks) means the compound has higher relative abundance in CW2. The molecular formulas with top 10 positive and top 10 negative relative abundances are also shown in the plot.

RA molecular formulas assigned to the cloud sample with a nighttime composite than the daytime sample ( 2 versus 1 nitrogen atom), likely reflecting the nighttime $\mathrm{NO}_{\mathrm{x}}$ chemistry. The molecular composition determined from ultrahighresolution FT-ICR mass spectrometry provides insights into the organic composition of cloud water AOM in the Rocky Mountain area and indicates significant biogenic SOA and residential wood combustion contributions to the overall composition.

\section{Supplementary material related to this article is available online at http://www.atmos-chem-phys.net/13/ 12343/2013/acp-13-12343-2013-supplement.pdf.}

Acknowledgements. Funding for this research was provided by the Michigan Tech Research for Excellence program. The authors thank M. Soule and E. Kujawinski of the Woods Hole Oceanographic Institution (WHOI) Mass Spectrometry Facility for assistance with data acquisition (NSF OCE-0619608 and Gordon and Betty Moore Foundation). Y. Zhao was supported by the Chinese Scholarship Council. The authors thank J. Nordeng of Michigan Technological University for building the new stainless steel cloud sieves used in this study. We thank I. McCubbin for help with sampling and instrumentation, and Doug Lowenthal for helpful discussions. Finally, we thank the two anonymous referees for helpful suggestions to improve the manuscript. The Steamboat Ski Resort provided logistical support and in-kind donations. The DRI's SPL is an equal opportunity service provider and employer and is a permittee of the Medicine-Bow Routt National Forests.

Edited by: F. Keutsch

\section{References}

Aiken, A. C., DeCarlo, P. F., and Jimenez, J. L.: Elemental Analysis of Organic Species with Electron Ionization High-Resolution Mass Spectrometry, Anal. Chem., 79, 8350-8358, 2007.

Aiken, A. C., DeCarlo, P. F., Kroll, J. H., Worsnop, D. R., Huffman, J. A., Docherty, K. S., Ulbrich, I. M., Mohr, C., Kimmel, J. R., Sueper, D., Sun, Y. L., Zhang, Q., Trimborn, A., Northway, M., Ziemann, P. J., Canagaratna, M. R., Onasch, T. B., Alfarra, M. R., Prevot, A. S. H., Dommen, J., Duplissy, J., Metzger, A., Baltensperger, U., and Jimenez, J. L.: O/C and OM/OC Ratios of Primary, Secondary, and Ambient Organic Aerosols with HighResolution Time-of-Flight Aerosol Mass Spectrometry, Environ. Sci. Technol., 42, 4478-4485, 2008.

Allen, D. T., Palen, E. J., Haimov, M. I., Hering, S. V., and Young, J. R.: Fourier Transform Infrared Spectroscopy of Aerosol Collected in a Low Pressure Impactor (LPI/FTIR), Method Development and Field Calibration, Aerosol Sci. Tech., 21, 325-342, 1994.

Altieri, K. E., Seitzinger, S. P., Carlton, A. G., Turpin, B. J., Klein, G. C., and Marshall, A. G.: Oligomers formed through in-cloud methylglyoxal reactions: Chemical composition, properties, and mechanisms investigated by ultra-high resolution FT-ICR mass spectrometry, Atmos. Environ., 42, 1476-1490, 2008.

Altieri, K. E., Turpin, B. J., and Seitzinger, S. P.: Composition of Dissolved Organic Nitrogen in Continental Precipitation Investigated by Ultra-High Resolution FT-ICR Mass Spectrometry, Environ. Sci. Technol., 43, 6950-6955, 2009a.

Altieri, K. E., Turpin, B. J., and Seitzinger, S. P.: Oligomers, organosulfates, and nitrooxy organosulfates in rainwater identified by ultra-high resolution electrospray ionization FTICR mass spectrometry, Atmos. Chem. Phys., 9, 2533-2542, doi:10.5194/acp-9-2533-2009, 2009b.

Altieri, K. E., Hastings, M. G., Peters, A. J., and Sigman, D. M.: Molecular characterization of water soluble organic nitrogen in marine rainwater by ultra-high resolution electrospray ionization mass spectrometry, Atmos. Chem. Phys., 12, 3557-3571, doi:10.5194/acp-12-3557-2012, 2012. 
Amin, H., Atkins, P. T., Russo, R. S., Brown, A. W., Sive, B., Hallar, A. G., and Huff Hartz, K. E.: Effect of Bark Beetle Infestation on Secondary Organic Aerosol Precursor Emissions, Environ. Sci. Technol., 46, 5696-5703, 2012.

Arp, H. P. H. and Goss, K.-U.: Ambient Gas/Particle Partitioning, 3. Estimating Partition Coefficients of Apolar, Polar, and Ionizable Organic Compounds by Their Molecular Structure, Environ. Sci. Technol., 43, 1923-1929, 2009.

Bateman, A. P., Nizkorodov, S. A., Laskin, J., and Laskin, A.: Timeresolved molecular characterization of limonene/ozone aerosol using high-resolution electrospray ionization mass spectrometry, Phys. Chem. Chem. Phys., 11, 7931-7942, 2009.

Bateman, A. P., Nizkorodov, S. A., Laskin, J., and Laskin, A.: HighResolution Electrospray Ionization Mass Spectrometry Analysis of Water-Soluble Organic Aerosols Collected with a Particle into Liquid Sampler, Anal. Chem., 82, 8010-8016, 2010.

Bateman, A. P., Nizkorodov, S. A., Laskin, J., and Laskin, A.: Photolytic processing of secondary organic aerosols dissolved in cloud droplets, Phys. Chem. Chem. Phys., 13, 12199-12212, doi:10.1039/C1CP20526A, 2011.

Betterton, E. A. and Hoffmann, M. R.: Henry's law constants of some environmentally important aldehydes, Environ. Sci. Technol., 22, 1415-1418, 1988.

Blakney, G. T., Hendrickson, C. L., and Marshall, A. G.: Predator data station, a fast data acquisition system for advanced FTICR MS experiments, Int. J. Mass Spectrom, 306, 246-252, doi:10.1016/J.IJMS.2011.03.009, 2011.

Blando, J. D. and Turpin, B. J.: Secondary organic aerosol formation in cloud and fog droplets, a literature evaluation of plausibility, Atmos. Environ., 34, 1623-1632, 2000.

Bruns, E. A., Perraud, V., Zelenyuk, A., Ezell, M. J., Johnson, S. N., Yu, Y., Imre, D., Finlayson-Pitts, B. J., and Alexander, M. L.: Comparison of FTIR and Particle Mass Spectrometry for the Measurement of Particulate Organic Nitrates, Environ. Sci. Technol., 44, 1056-1061, 2010.

Cappiello, A., De Simoni, E., Fiorucci, C., Mangani, F., Palma, P., Trufelli, H., Decesari, S., Facchini, M. C., and Fuzzi, S.: Molecular Characterization of the Water-Soluble Organic Compounds in Fogwater by ESIMS/MS, Environ. Sci. Technol., 37, 1229-1240, 2003.

Carlton, A. G., Turpin, B. J., Altieri, K. E., Seitzinger, S., Reff, A., Lim, H.-J., and Ervens, B.: Atmospheric oxalic acid and SOA production from glyoxal, Results of aqueous photooxidation experiments, Atmos. Environ., 41, 7588-7602, 2007.

Charbouillot, T., Gorini, S., Voyard, G., Parazols, M., Brigante, M., Deguillaume, L., Delort, A.-M., and Mailhot, G.: Mechanism of carboxylic acid photooxidation in atmospheric aqueous phase, Formation, fate and reactivity, Atmos. Environ., 56, 1-8, 2012.

Claeys, M., Szmigielski, R., Vermeylen, R., Wang, W., Shalamzari, M., and Maenhaut, W.: Tracers for Biogenic Secondary Organic Aerosol from $\alpha$-Pinene and Related Monoterpenes, An Overview, in: Disposal of Dangerous Chemicals in Urban Areas and Mega Cities, edited by: Barnes, I. and Rudziński, K. J., NATO Science for Peace and Security Series C, Environmental Security, Springer Netherlands, 227-238, 2013.

Collett, J. L., Bator, A., Sherman, D. E., Moore, K. F., Hoag, K. J., Demoz, B. B., Rao, X., and Reilly, J. E.: The chemical composition of fogs and intercepted clouds in the United States, Atmos. Res., 64, 29-40, 2002.
Collett, J. L., Herckes, P., Youngster, S., and Lee, T.: Processing of atmospheric organic matter by California radiation fogs, Atmos. Res., 87, 232-241, 2008.

Crahan, K. K., Hegg, D., Covert, D. S., and Jonsson, H.: An exploration of aqueous oxalic acid production in the coastal marine atmosphere, Atmos. Environ., 38, 3757-3764, 2004.

Dalbec, M. M., Zhao, Y., Fisseha, R., Putman, A. L., Rahn, T. A., and Mazzoleni, L. R.: Comprehensive biogenic secondary organic aerosol characterization and identification of specific indicator molecular formulas, in prep., 2013.

Decesari, S., Facchini, M. C., Fuzzi, S., McFiggans, G. B., Coe, H., and Bower, K. N.: The water-soluble organic component of sizesegregated aerosol, cloud water and wet depositions from Jeju Island during ACE-Asia, Atmos. Environ., 39, 211-222, 2005.

De Haan, D. O., Tolbert, M. A., and Jimenez, J. L.: Atmospheric condensed-phase reactions of glyoxal with methylamine, Geophys. Res. Lett., 36, L11819, doi:10.1029/2009GL037441, 2009.

De Haan, D. O., Hawkins, L. N., Kononenko, J. A., Turley, J. J., Corrigan, A. L., Tolbert, M. A., and Jimenez, J. L.: Formation of Nitrogen-Containing Oligomers by Methylglyoxal and Amines in Simulated Evaporating Cloud Droplets, Environ. Sci. Technol., 45, 984-991, 2010.

Deininger, C. K. and Saxena, V. K.: A validation of back trajectories of air masses by principal component analysis of ion concentrations in cloud water, Atmos. Environ., 31, 295-300, 1997.

Ervens, B., Turpin, B. J., and Weber, R. J.: Secondary organic aerosol formation in cloud droplets and aqueous particles (aqSOA): a review of laboratory, field and model studies, Atmos. Chem. Phys., 11, 11069-11102, doi:10.5194/acp-1111069-2011, 2011.

Facchini, M. C., Fuzzi, S., Zappoli, S., Andracchio, A., Gelencsér, A., Kiss, G., Krivácsy, Z., Mészáros, E., Hansson, H.-C., Alsberg, T., and Zebühr, Y.: Partitioning of the organic aerosol component between fog droplets and interstitial air, J. Geophys. Res.Atmos., 104, 26821-26832, 1999.

Feng, J. and Möller, D.: Characterization of Water-Soluble Macromolecular Substances in Cloud Water, J. Atmos. Chem., 48, 217233, 2004.

Fry, J. L., Draper, D. C., Zarzana, K. J., Campuzano-Jost, P., Day, D. A., Jimenez, J. L., Brown, S. S., Cohen, R. C., Kaser, L., Hansel, A., Cappellin, L., Karl, T., Hodzic Roux, A., Turnipseed, A., Cantrell, C., Lefer, B. L., and Grossberg, N.: Observations of gas- and aerosol-phase organic nitrates at BEACHON-RoMBAS 2011, Atmos. Chem. Phys., 13, 8585-8605, doi:10.5194/acp-138585-2013, 2013

Galloway, M. M., Chhabra, P. S., Chan, A. W. H., Surratt, J. D., Flagan, R. C., Seinfeld, J. H., and Keutsch, F. N.: Glyoxal uptake on ammonium sulphate seed aerosol: reaction products and reversibility of uptake under dark and irradiated conditions, Atmos. Chem. Phys., 9, 3331-3345, doi:10.5194/acp-9-3331-2009, 2009.

Garnes, L. A. and Allen, D. T.: Size Distributions of Organonitrates in Ambient Aerosol Collected in Houston, Texas, Aerosol Sci. Technol., 36, 983-992, 2002.

Gilardoni, S., Liu, S., Takahama, S., Russell, L. M., Allan, J. D., Steinbrecher, R., Jimenez, J. L., De Carlo, P. F., Dunlea, E. J., and Baumgardner, D.: Characterization of organic ambient aerosol during MIRAGE 2006 on three platforms, Atmos. Chem. Phys., 9, 5417-5432, doi:10.5194/acp-9-5417-2009, 2009. 
Gioda, A., Reyes-Rodríguez, G. J., Santos-Figueroa, G., Collett, Jr., J. L., Decesari, S., Ramos, M. D. C. K. V., Bezerra Netto, H. J. C., de Aquino Neto, F. R., and Mayol-Bracero, O. L.: Speciation of water-soluble inorganic, organic, and total nitrogen in a background marine environment, Cloud water, rainwater, and aerosol particles, J. Geophys. Res.-Atmos., 116, D05203, doi:10.1029/2010JD015010, 2011.

Gioda, A., Mayol-Bracero, O. L., Scatena, F. N., Weathers, K. C., Mateus, V. L., and McDowell, W. H.: Chemical constituents in clouds and rainwater in the Puerto Rican rainforest, Potential sources and seasonal drivers, Atmos. Environ., 68, 208-220, 2013.

Gómez-González, Y., Surratt, J. D., Cuyckens, F., Szmigielski, R., Vermeylen, R., Jaoui, M., Lewandowski, M., Offenberg, J. H., Kleindienst, T. E., Edney, E. O., Blockhuys, F., Van Alsenoy, C., Maenhaut, W., and Claeys, M.: Characterization of organosulfates from the photooxidation of isoprene and unsaturated fatty acids in ambient aerosol using liquid chromatography/(-) electrospray ionization mass spectrometry, J. Mass Spectrom., 43, 371-382, 2008.

Graber, E. R. and Rudich, Y.: Atmospheric HULIS: How humic-like are they? A comprehensive and critical review, Atmos. Chem. Phys., 6, 729-753, doi:10.5194/acp-6-729-2006, 2006.

Graedel, T. E. and Weschler, C. J.: Chemistry within aqueous atmospheric aerosols and raindrops, Rev. Geophys., 19, 505-539, 1981.

Hallar, A. G., Lowenthal, D. H., Clegg, S. L., Samburova, V., Taylor, N., Mazzoleni, L. R., Zielinska, B. K., Kristensen, T. B., Chirokova, G., McCubbin, I. B., Dodson, C., and Collins, D.: Chemical and Hygroscopic Properties of Aerosol Organics at Storm Peak Laboratory, J. Geophys. Res.-Atmos.,118, 47674779, doi:10.1002/jgrd.50373, 2013.

Hatch, L. E., Creamean, J. M., Ault, A. P., Surratt, J. D., Chan, M. N., Seinfeld, J. H., Edgerton, E. S., Su, Y., and Prather, K. A.: Measurements of Isoprene-Derived Organosulfates in Ambient Aerosols by Aerosol Time-of-Flight Mass Spectrometry - Pt. 1, Single Particle Atmospheric Observations in Atlanta, Environ. Sci. Technol., 45, 5105-5111, 2011.

Havers, N., Burba, P., Lambert, J., and Klockow, D.: Spectroscopic Characterization of Humic-Like Substances in Airborne Particulate Matter, J. Atmos. Chem., 29, 45-54, 1998.

Hawthorne, S. B., Miller, D. J., Langenfeld, J. J., and Krieger, M. S.: PM-10 high-volume collection and quantitation of semi- and nonvolatile phenols, methoxylated phenols, alkanes, and polycyclic aromatic hydrocarbons from winter urban air and their relationship to wood smoke emissions, Environ. Sci. Technol., 26, 2251-2262, 1992.

Heald, C. L., Jacob, D. J., Park, R. J., Russell, L. M., Huebert, B. J., Seinfeld, J. H., Liao, H., and Weber, R. J.: A large organic aerosol source in the free troposphere missing from current models, Geophys. Res. Lett., 32, L18809, doi:10.1029/2005g1023831, 2005.

Heald, C. L., Kroll, J. H., Jimenez, J. L., Docherty, K. S., DeCarlo, P. F., Aiken, A. C., Chen, Q., Martin, S. T., Farmer, D. K., and Artaxo, P.: A simplified description of the evolution of organic aerosol composition in the atmosphere, Geophys. Res. Lett., 37, L08803, doi:10.1029/2010GL042737, 2010.

Herckes, P., Valsaraj, K. T., and Collett, J. L.: A review of observations of organic matter in fogs and clouds: Origin, processing and fate, Atmos. Res., 132, 434-449, 2013.
Herckes, P., Leenheer, J. A., and Collett, J. L.: Comprehensive Characterization of Atmospheric Organic Matter in Fresno, California Fog Water, Environ. Sci. Technol., 41, 393-399, 2007.

Herckes, P., Hannigan, M. P., Trenary, L., Lee, T., and Collett, J. L.: Organic compounds in radiation fogs in Davis (California), Atmos. Res., 64, 99-108, 2002a.

Herckes, P., Lee, T., Trenary, L., Kang, G., Chang, H., and Collett, J. L.: Organic Matter in Central California Radiation Fogs, Environ. Sci. Technol., 36, 4777-4782, 2002b.

Herrmann, H., Hoffmann, D., Schaefer, T., Bräuer, P., and Tilgner, A.: Tropospheric Aqueous-Phase Free-Radical Chemistry: Radical Sources, Spectra, Reaction Kinetics and Prediction Tools, Chem. Phys. Chem., 11, 3796-3822, 2010.

Hertkorn, N., Frommberger, M., Witt, M., Koch, B. P., SchmittKopplin, P., and Perdue, E. M.: Natural Organic Matter and the Event Horizon of Mass Spectrometry, Anal. Chem., 80, 89088919, 2008.

Hindman, E. E., Borys, R. D., Lowenthal, D. H. and Phillip, N.: Long-term, wintertime aerosol, cloud and precipitation measurements in the Northern Colorado Rocky Mountains, USA, Atmos. Res., 82, 194-202, 2006.

Hindman, E., Campbell, M. A., and Borys, R. D.: A $10 \mathrm{yr}$ record of cloud-droplet physical and chemical properties at a mountaintop site in Colorado, J. Appl. Meteor, 33, 797-807, 1994.

Hindman, E. E., Carter, E. J., Borys, R. D., and Mitchell, D. L.: Collecting Supercooled Cloud Droplets as a Function of Droplet Size, J. Atmos. Oceanic Tech., 9, 337-353, 1992.

Hughey, C. A., Hendrickson, C. L., Rodgers, R. P., Marshall, A. G., and Qian, K.: Kendrick Mass Defect Spectrum: A Compact Visual Analysis for Ultrahigh-Resolution Broadband Mass Spectra, Anal. Chem., 73, 4676-4681, 2001.

Iinuma, Y., Muller, C., Berndt, T., Boge, O., Claeys, M., and Herrmann, H.: Evidence for the Existence of Organosulfates from aPinene Ozonolysis in Ambient Secondary Organic Aerosol, Environ. Sci. Technol., 41, 6678-6683, 2007.

Jimenez, J. L., Canagaratna, M. R., Donahue, N. M., Prevot, A. S. H., Zhang, Q., Kroll, J. H., DeCarlo, P. F., Allan, J. D., Coe, H., Ng, N. L., Aiken, A. C., Docherty, K. S., Ulbrich, I. M., Grieshop, A. P., Robinson, A. L., Duplissy, J., Smith, J. D., Wilson, K. R., Lanz, V. A., Hueglin, C., Sun, Y. L., Tian, J., Laaksonen, A., Raatikainen, T., Rautiainen, J., Vaattovaara, P., Ehn, M., Kulmala, M., Tomlinson, J. M., Collins, D. R., Cubison, M. J., E., Dunlea, J., Huffman, J. A., Onasch, T. B., Alfarra, M. R., Williams, P. I., Bower, K., Kondo, Y., Schneider, J., Drewnick, F., Borrmann, S., Weimer, S., Demerjian, K., Salcedo, D., Cottrell, L., Griffin, R., Takami, A., Miyoshi, T., Hatakeyama, S., Shimono, A., Sun, J. Y., Zhang, Y. M., Dzepina, K., Kimmel, J. R., Sueper, D., Jayne, J. T., Herndon, S. C., Trimborn, A. M., Williams, L. R., Wood, E. C., Middlebrook, A. M., Kolb, C. E., Baltensperger, U., and Worsnop, D. R.: Evolution of Organic Aerosols in the Atmosphere, Science, 326, 1525-1529, 2009.

Keene, W. C., Mosher, B. W., Jacob, D. J., Munger, J. W., Talbot, R. W., Artz, R. S., Maben, J. R., Daube, B. C., and Galloway, J. N.: Carboxylic acids in clouds at a high-elevation forested site in central Virginia, J. Geophys. Res.-Atmos., 100, 9345-9357, 1995.

Kesselmeier, J. and Staudt, M.: Biogenic Volatile Organic Compounds (VOC), An Overview on Emission, Physiology and Ecology, J. Atmos. Chem., 33, 23-88, 1999. 
Kim, S., Kramer, R. W., and Hatcher, P. G.: Graphical Method for Analysis of Ultrahigh-Resolution Broadband Mass Spectra of Natural Organic Matter, the Van Krevelen Diagram, Anal. Chem., 75, 5336-5344, 2003.

Koch, B. P., Witt, M., Engbrodt, R., Dittmar, T., and Kattner, G.: Molecular formulae of marine and terrigenous dissolved organic matter detected by electrospray ionization Fourier transform ion cyclotron resonance mass spectrometry, Geochim. Cosmochim. Ac., 69, 3299-3308, 2005.

Koch, B. P., Dittmar, T., Witt, M., and Kattner, G.: Fundamentals of Molecular Formula Assignment to Ultrahigh Resolution Mass Data of Natural Organic Matter, Anal. Chem., 79, 1758-1763, 2007.

Krivácsy, Z., Kiss, G., Varga, B., Galambos, I., Sárvári, Z., Gelencsér, A., Molnár, Á., Fuzzi, S., Facchini, M. C., Zappoli, S., Andracchio, A., Alsberg, T., Hansson, H. C., and Persson, L.: Study of humic-like substances in fog and interstitial aerosol by sizeexclusion chromatography and capillary electrophoresis, Atmos. Environ., 34, 4273-4281, 2000.

Kroll, J. H. and Seinfeld, J. H.: Chemistry of secondary organic aerosol, Formation and evolution of low-volatility organics in the atmosphere, Atmos. Environ., 42, 3593-3624, 2008.

Kroll, J. H., Donahue, N. M., Jimenez, J. L., Kessler, S. H., Canagaratna, M. R., Wilson, K. R., Altieri, K. E., Mazzoleni, L. R., Wozniak, A. S., Bluhm, H., Mysak, E. R., Smith, J. D., Kolb, C. E., and Worsnop, D. R.: Carbon oxidation state as a metric for describing the chemistry of atmospheric organic aerosol, Nat. Chem., 3, 133-139, 2011.

Kujawinski, E. B.: Electrospray Ionization Fourier Transform Ion Cyclotron Resonance Mass Spectrometry (ESI FT-ICR MS), Characterization of Complex Environmental Mixtures, Environ. Forensics, 3, 207-216, 2002.

Kujawinski, E. B., Hatcher, P. G., and Freitas, M. A.: HighResolution Fourier Transform Ion Cyclotron Resonance Mass Spectrometry of Humic and Fulvic Acids, Improvements and Comparisons, Anal. Chem., 74, 413-419, 2002.

Kundu, S., Fisseha, R., Putman, A. L., Rahn, T. A., and Mazzoleni, L. R.: High molecular weight SOA formation during limonene ozonolysis: insights from ultrahigh-resolution FT-ICR mass spectrometry characterization, Atmos. Chem. Phys., 12, 5523-5536, doi:10.5194/acp-12-5523-2012, 2012.

Kundu, S., Quraishi, T. A., Yu, G., Suarez, C., Keutsch, F. N., and Stone, E. A.: Evidence and quantitation of aromatic organosulfates in ambient aerosols in Lahore, Pakistan, Atmos. Chem. Phys., 13, 4865-4875, doi:10.5194/acp-13-4865-2013, 2013.

Laj, P., Fuzzi, S., Facchini, M. C., Lind, J. A., Orsi, G., Preiss, M., Maser, R., Jaeschke, W., Seyffer, E., Helas, G., Acker, K., Wieprecht, W., Möller, D., Arends, B. G., Mols, J. J., Colvile, R. N., Gallagher, M. W., Beswick, K. M., Hargreaves, K. J., Storeton-West, R. L., and Sutton, M. A.: Cloud processing of soluble gases, Atmos. Environ., 31, 2589-2598, 1997.

Laskin, A., Smith, J. S., and Laskin, J.: Molecular Characterization of Nitrogen-Containing Organic Compounds in Biomass Burning Aerosols Using High-Resolution Mass Spectrometry, Environ. Sci. Technol., 43, 3764-3771, 2009.

LeClair, J. P., Collett, J. L., and Mazzoleni, L. R.: Fragmentation Analysis of Water-Soluble Atmospheric Organic Matter Using Ultrahigh-Resolution FT-ICR Mass Spectrometry, Environ. Sci. Technol., 46, 4312-4322, 2012.
Lee, A. K. Y., Hayden, K. L., Herckes, P., Leaitch, W. R., Liggio, J., Macdonald, A. M., and Abbatt, J. P. D.: Characterization of aerosol and cloud water at a mountain site during WACS 2010: secondary organic aerosol formation through oxidative cloud processing, Atmos. Chem. Phys., 12, 7103-7116, doi:10.5194/acp-12-7103-2012, 2012.

Lee, A. K. Y., Herckes, P., Leaitch, W. R., Macdonald, A. M., and Abbatt, J. P. D.: Aqueous $\mathrm{OH}$ oxidation of ambient organic aerosol and cloud water organics: Formation of highly oxidized products, Geophys. Res. Lett., 38, L11805, doi:10.1029/2011GL047439, 2011.

Lerdau, M., Dilts, S. B., Westberg, H., Lamb, B. K., and Allwine, E. J.: Monoterpene emission from ponderosa pine, J. Geophys. Res.-Atmos., 99, 16609-16615, 1994.

Liggio, J., Li, S.-M., and McLaren, R.: Reactive uptake of glyoxal by particulate matter, J. Geophys. Res.-Atmos., 110, D10304, doi:10.1029/2004JD005113, 2005.

Liggio, J., Li, S.-M., Brook, J. R., and Mihele, C.: Direct polymerization of isoprene and $\alpha$-pinene on acidic aerosols, Geophys. Res. Lett., 34, L05814, doi:10.1029/2006GL028468, 2007.

Lim, Y. B., Tan, Y., Perri, M. J., Seitzinger, S. P., and Turpin, B. J.: Aqueous chemistry and its role in secondary organic aerosol (SOA) formation, Atmos. Chem. Phys., 10, 1052110539, doi:10.5194/acp-10-10521-2010, 2010.

Limbeck, A. and Puxbaum, H.: Dependence of in-cloud scavenging of polar organic aerosol compounds on the water solubility, J. Geophys. Res.-Atmos., 105, 19857-19867, 2000.

Lin, P., Rincon, A. G., Kalberer, M., and Yu, J. Z.: Elemental Composition of HULIS in the Pearl River Delta Region, China, Results Inferred from Positive and Negative Electrospray High Resolution Mass Spectrometric Data, Environ. Sci. Technol., 46, 7454-7462, 2012a.

Lin, P., Yu, J. Z., Engling, G., and Kalberer, M.: Organosulfates in Humic-like Substance Fraction Isolated from Aerosols at Seven Locations in East Asia, A Study by Ultra-High-Resolution Mass Spectrometry, Environ. Sci. Technol., 46, 13118-13127, 2012 b.

Lowenthal, D. H., Borys, R. D., and Wetzel, M. A.: Aerosol distributions and cloud interactions at a mountaintop laboratory, J. Geophys. Res.-Atmos., 107, 4345, doi:10.1029/2001JD002046, 2002.

Lowenthal, D. H., Borys, R. D., Choularton, T. W., Bower, K. N., Flynn, M. J., and Gallagher, M. W.: Parameterization of the cloud droplet - sulfate relationship, Atmos. Environ., 38, 287-292, 2004.

Lüttke, J. and Levsen, K.: Phase partitioning of phenol and nitrophenols in clouds, Atmos. Environ., 31, 2649-2655, 1997.

Lüttke, J., Scheer, V., Levsen, K., Wünsch, G., Neil Cape, J., Hargreaves, K. J., Storeton-West, R. L., Acker, K., Wieprecht, W., and Jones, B.: Occurrence and formation of nitrated phenols in and out of cloud, Atmos. Environ., 31, 2637-2648, 1997.

Marinoni, A., Laj, P., Sellegri, K., and Mailhot, G.: Cloud chemistry at the Puy de Dôme: variability and relationships with environmental factors, Atmos. Chem. Phys., 4, 715-728, doi:10.5194/acp-4-715-2004, 2004.

Marshall, A. G., Hendrickson, C. L., and Jackson, G. S.: Fourier transform ion cyclotron resonance mass spectrometry: A primer, Mass Spectrom. Rev., 17, 1-35, 1998.

Mazzoleni, L. R., Zielinska, B., and Moosmüller, H.: Emissions of Levoglucosan, Methoxy Phenols, and Organic Acids from Pre- 
scribed Burns, Laboratory Combustion of Wildland Fuels, and Residential Wood Combustion, Environ. Sci. Technol., 41, 21152122, 2007.

Mazzoleni, L. R., Ehrmann, B. M., Shen, X., Marshall, A. G., and Collett, J. L.: Water-Soluble Atmospheric Organic Matter in Fog, Exact Masses and Chemical Formula Identification by UltrahighResolution Fourier Transform Ion Cyclotron Resonance Mass Spectrometry, Environ. Sci. Technol., 44, 3690-3697, 2010.

Mazzoleni, L. R., Saranjampour, P., Dalbec, M. M., Samburova, V., Hallar, A. G., Zielinska, B., Lowenthal, D. H., and Kohl, S.: Identification of water-soluble organic carbon in non-urban aerosols using ultrahigh-resolution FT-ICR mass spectrometry, organic anions, Environ. Chem., 9, 285-297, 2012.

McLafferty, F. W. and Tureek, F.: Interpretation of mass spectra, 4th ed., Sausalito, CA, 1993, edited by: Minerath, E. C. and Elrod, M. J., Assessing the Potential for Diol and Hydroxy Sulfate Ester Formation from the Reaction of Epoxides in Tropospheric Aerosols, Environ. Sci. Technol., 43, 1386-1392, 2009.

Minerath, E. C. and Elrod, M. J.: Assessing the Potential for Diol and Hydroxy Sulfate Ester Formation from the Reaction of Epoxides in Tropospheric Aerosols, Environ. Sci. Technol., 43, 13861392, 2009.

Munger, J. W., Jacob, D. J., Daube, B. C., Horowitz, L. W., Keene, W. C., and Heikes, B. G.: Formaldehyde, glyoxal, and methylglyoxal in air and cloudwater at a rural mountain site in central Virginia, J. Geophys. Res.-Atmos., 100, 9325-9333, 1995.

Ng, N. L., Canagaratna, M. R., Zhang, Q., Jimenez, J. L., Tian, J., Ulbrich, I. M., Kroll, J. H., Docherty, K. S., Chhabra, P. S., Bahreini, R., Murphy, S. M., Seinfeld, J. H., Hildebrandt, L., Donahue, N. M., DeCarlo, P. F., Lanz, V. A., Prévôt, A. S. H., Dinar, E., Rudich, Y., and Worsnop, D. R.: Organic aerosol components observed in Northern Hemispheric datasets from Aerosol Mass Spectrometry, Atmos. Chem. Phys., 10, 46254641, doi:10.5194/acp-10-4625-2010, 2010.

Nielsen, T., Platz, J., Granby, K., Hansen, A. B., Skov, H., and Egeløv, A. H.: Particulate organic nitrates: sampling and night/day variation, Atmos. Environ., 32, 2601-2608, 1998.

Obrist, D., Hallar, A. G., McCubbin, I., Stephens, B. B., and Rahn, T.: Atmospheric mercury concentrations at Storm Peak Laboratory in the Rocky Mountains: Evidence for long-range transport from Asia, boundary layer contributions, and plant mercury uptake, Atmos. Environ., 42, 7579-7589, 2008.

Perraud, V., Bruns, E. A., Ezell, M. J., Johnson, S. N., Greaves, J., and Finlayson-Pitts, B. J.: Identification of Organic Nitrates in the NO3 Radical Initiated Oxidation of $\alpha$-Pinene by Atmospheric Pressure Chemical Ionization Mass Spectrometry, Environ. Sci. Technol., 44, 5887-5893, 2010.

Perri, M. J., Seitzinger, S., and Turpin, B. J.: Secondary organic aerosol production from aqueous photooxidation of glycolaldehyde, Laboratory experiments, Atmos. Environ., 43, 1487-1497, 2009.

Pratt, K. A., Fiddler, M. N., Shepson, P. B., Carlton, A. G., and Surratt, J. D.: Organosulfates in cloud water above the Ozarks' isoprene source region, Atmos. Environ., 77, 231-238, 2013.

Pruppacher, H. R. and Klett, J. D.: Microphysics of clouds and precipitation, 2nd ed., Atmospheric and Oceanographic Sciences Library, Kluwer Academic Publishers, Boston, Massachusetts, 18, 1996.
Putman, A. L., Offenberg, J. H., Fisseha, R., Kundu, S., Rahn, T. A., and Mazzoleni, L. R.: Ultrahigh-resolution FT-ICR mass spectrometry characterization of a-pinene ozonolysis SOA, Atmos. Environ., 46, 164-172, 2012.

Reemtsma, T., These, A., Venkatachari, P., Xia, X., Hopke, P. K., Springer, A., and Linscheid, M.: Identification of Fulvic Acids and Sulfated and Nitrated Analogues in Atmospheric Aerosol by Electrospray Ionization Fourier Transform Ion Cyclotron Resonance Mass Spectrometry, Anal. Chem., 78, 8299-8304, 2006.

Reinhardt, A., Emmenegger, C., Gerrits, B., Panse, C., Dommen, J., Baltensperger, U., Zenobi, R., and Kalberer, M.: Ultrahigh Mass Resolution and Accurate Mass Measurements as a Tool To Characterize Oligomers in Secondary Organic Aerosols, Anal. Chem., 79, 4074-4082, 2007.

Reyes-Rodríguez, G. J., Gioda, A., Mayol-Bracero, O. L., and Collett, J. L.: Organic carbon, total nitrogen, and water-soluble ions in clouds from a tropical montane cloud forest in Puerto Rico, Atmos. Environ., 43, 4171-4177, 2009.

Rincon, A. G., Calvo, A. I., Dietzel, M., and Kalberer, M.: Seasonal differences of urban organic aerosol composition - an ultra-high resolution mass spectrometry study, Environ. Chem., 9, 298-319, 2012.

Romero, F., and Oehme, M.: Organosulfates - A New Component of Humic-Like Substances in Atmospheric Aerosols?, J. Atmos. Chem., 52, 283-294, 2005.

Sagebiel, J. C. and Seiber, J. N.: Studies on the occurrence and distribution of wood smoke marker compounds in foggy atmospheres, Enviro. Toxicol. Chem., 12, 813-822, 1993.

Samburova, V., Hallar, A. G., Mazzoleni, L. R., Saranjampour, P., Lowenthal, D., Kohl, S., and Zielinska, B.: Composition of water-soluble organic carbon in nonurban atmospheric aerosol collected at the Storm Peak Laboratory, Environ. Chem., http: //dx.doi.org/10.1071/EN13079, 2013.

Samy, S., Mazzoleni, L. R., Mishra, S., Zielinska, B., and Hallar, A. G.: Water-soluble organic compounds at a mountain-top site in Colorado, USA, Atmos. Environ., 44, 1663-1671, 2010.

Saranjampour, P.: Characterization of water-soluble organic compounds in ambient aerosol using ultrahigh-resolution electrospray ionization fourer transform ion cyclotron resonance mass spectrometry, MS, Department of Chemistry, Michigan Technological University, Houghton, Michigan, 2012.

Sareen, N., Schwier, A. N., Shapiro, E. L., Mitroo, D., and McNeill, V. F.: Secondary organic material formed by methylglyoxal in aqueous aerosol mimics, Atmos. Chem. Phys., 10, 997-1016, doi:10.5194/acp-10-997-2010, 2010.

Schmitt-Kopplin, P., Gelencseìr, A., Dabek-Zlotorzynska, E., Kiss, G., Hertkorn, N., Harir, M., Hong, Y., and Gebefügi, I.: Analysis of the Unresolved Organic Fraction in Atmospheric Aerosols with Ultrahigh-Resolution Mass Spectrometry and Nuclear Magnetic Resonance Spectroscopy: Organosulfates As Photochemical Smog Constituents $\dagger$, Anal. Chem., 82, 8017-8026, 2010.

Shapiro, E. L., Szprengiel, J., Sareen, N., Jen, C. N., Giordano, M. R., and McNeill, V. F.: Light-absorbing secondary organic material formed by glyoxal in aqueous aerosol mimics, Atmos. Chem. Phys., 9, 2289-2300, doi:10.5194/acp-9-2289-2009, 2009.

Simeonov, V., Kalina, M., Tsakovski, S., and Puxbaum, H.: Multivariate statistical study of simultaneously monitored cloud water, aerosol and rainwater data from different elevation levels in an 
alpine valley (Achenkirch, Tyrol, Austria), Talanta, 61, 519-528, 2003.

Sleighter, R. L. and Hatcher, P. G.: The application of electrospray ionization coupled to ultrahigh resolution mass spectrometry for the molecular characterization of natural organic matter, J. Mass Spectrom., 42, 559-574, 2007.

Sleighter, R. L. and Hatcher, P. G.: Molecular characterization of dissolved organic matter (DOM) along a river to ocean transect of the lower Chesapeake Bay by ultrahigh resolution electrospray ionization Fourier transform ion cyclotron resonance mass spectrometry, Mar. Chem., 110, 140-152, 2008.

Sorooshian, A., Murphy, S. M., Hersey, S., Bahreini, R., Jonsson, H., Flagan, R. C., and Seinfeld, J. H.: Constraining the contribution of organic acids and AMS $m / z 44$ to the organic aerosol budget: On the importance of meteorology, aerosol hygroscopicity, and region, Geophys. Res. Lett., 37, L21807, doi:10.1029/2010GL044951, 2010.

Stenson, A. C., Marshall, A. G., and Cooper, W. T.: Exact Masses and Chemical Formulas of Individual Suwannee River Fulvic Acids from Ultrahigh Resolution Electrospray Ionization Fourier Transform Ion Cyclotron Resonance Mass Spectra, Anal. Chem., 75, 1275-1284, 2003.

Stone, E. A., Yang, L., Yu, L. E., and Rupakheti, M.: Characterization of organosulfates in atmospheric aerosols at Four Asian locations, Atmos. Environ., 47, 323-329, 2012.

Sun, Y. L., Zhang, Q., Zheng, M., Ding, X., Edgerton, E. S., and Wang, X.: Characterization and Source Apportionment of WaterSoluble Organic Matter in Atmospheric Fine Particles (PM2.5) with High-Resolution Aerosol Mass Spectrometry and GC-MS, Environ. Sci. Technol., 45, 4854-4861, 2011.

Sun, Y. L., Zhang, Q., Anastasio, C., and Sun, J.: Insights into secondary organic aerosol formed via aqueous-phase reactions of phenolic compounds based on high resolution mass spectrometry, Atmos. Chem. Phys., 10, 4809-4822, doi:10.5194/acp-104809-2010, 2010.

Surratt, J. D., Kroll, J. H., Kleindienst, T. E., Edney, E. O., Claeys, M., Sorooshian, A., Ng, N. L., Offenberg, J. H., Lewandowski, M., Jaoui, M., Flagan, R. C., and Seinfeld, J. H.: Evidence for Organosulfates in Secondary Organic Aerosol, Environ. Sci. Technol., 41, 517-527, 2006.

Surratt, J. D., Lewandowski, M., Offenberg, J. H., Jaoui, M., Kleindienst, T. E., Edney, E. O., and Seinfeld, J. H.: Effect of Acidity on Secondary Organic Aerosol Formation from Isoprene, Environ. Sci. Technol., 41, 5363-5369, 2007.

Surratt, J. D., Gómez-González, Y., Chan, A. W. H., Vermeylen, R., Shahgholi, M., Kleindienst, T. E., Edney, E. O., Offenberg, J. H., Lewandowski, M., Jaoui, M., Maenhaut, W., Claeys, M., Flagan, R. C., and Seinfeld, J. H.: Organosulfate Formation in Biogenic Secondary Organic Aerosol, J. Phys. Chem. A, 112, 8345-8378, 2008.

Tan, Y., Carlton, A. G., Seitzinger, S. P., and Turpin, B. J.: SOA from methylglyoxal in clouds and wet aerosols: Measurement and prediction of key products, Atmos. Environ., 44, 5218-5226, 2010.

van Pinxteren, D., Plewka, A., Hofmann, D., Müller, K., Kramberger, H., Svrcina, B., Bächmann, K., Jaeschke, W., Mertes, S., Collett, J. L., and Herrmann, H.: Schmücke hill cap cloud and valley stations aerosol characterisation during FEBUKO (II), Organic compounds, Atmos. Environ., 39, 4305-4320, 2005.
Volkamer, R., San Martini, F., Molina, L. T., Salcedo, D., Jimenez, J. L., and Molina, M. J.: A missing sink for gas-phase glyoxal in Mexico City, Formation of secondary organic aerosol, Geophys. Res. Lett., 34, L19807, doi:10.1029/2007GL030752, 2007.

Volkamer, R., Ziemann, P. J., and Molina, M. J.: Secondary Organic Aerosol Formation from Acetylene $\left(\mathrm{C}_{2} \mathrm{H}_{2}\right)$, seed effect on SOA yields due to organic photochemistry in the aerosol aqueous phase, Atmos. Chem. Phys., 9, 1907-1928, doi:10.5194/acp9-1907-2009, 2009.

Waxman, E. M., Dzepina, K., Ervens, B., Lee-Taylor, J., Aumont, B., Jimenez, J. L., Madronich, S., and Volkamer, R.: Secondary organic aerosol formation from semi- and intermediate-volatility organic compounds and glyoxal, Relevance of $\mathrm{O} / \mathrm{C}$ as a tracer for aqueous multiphase chemistry, Geophys. Res. Lett., 40, 978 982, 2013.

Weathers, K. C., Likens, G. E., Bormann, F. H., Bicknell, S. H., Bormann, B. T., Daube, B. C., Eaton, J. S., Galloway, J. N., Keene, W. C., Kimball, K. D., MacDowell, W. H., Siccama, T. G., Smiley, D., and Tarrant, R. A.: Cloudwater chemistry from ten sites in North America, Environ. Sci. Technol., 22, 1018-1026, 1988.

Wonaschuetz, A., Sorooshian, A., Ervens, B., Chuang, P. Y., Feingold, G., Murphy, S. M., de Gouw, J., Warneke, C., and Jonsson, H. H.: Aerosol and gas re-distribution by shallow cumulus clouds, An investigation using airborne measurements, J. Geophys. Res.-Atmos., 117, D17202, doi:10.1029/2012JD018089, 2012.

Wozniak, A. S., Bauer, J. E., Sleighter, R. L., Dickhut, R. M., and Hatcher, P. G.: Technical Note, Molecular characterization of aerosol-derived water soluble organic carbon using ultrahigh resolution electrospray ionization Fourier transform ion cyclotron resonance mass spectrometry, Atmos. Chem. Phys., 8, 50995111, doi:10.5194/acp-8-5099-2008, 2008.

Wu, Z., Rodgers, R. P., and Marshall, A. G.: Two- and ThreeDimensional van Krevelen Diagrams, A Graphical Analysis Complementary to the Kendrick Mass Plot for Sorting Elemental Compositions of Complex Organic Mixtures Based on Ultrahigh-Resolution Broadband Fourier Transform Ion Cyclotron Resonance Mass Measurements, Anal. Chem., 76, 25112516, 2004.

Yasmeen, F., Sauret, N., Gal, J.-F., Maria, P.-C., Massi, L., Maenhaut, W., and Claeys, M.: Characterization of oligomers from methylglyoxal under dark conditions: a pathway to produce secondary organic aerosol through cloud processing during nighttime, Atmos. Chem. Phys., 10, 3803-3812, doi:10.5194/acp-103803-2010, 2010.

Yu, S., Mathur, R., Schere, K., Kang, D., Pleim, J., Young, J., Tong, D., Pouliot, G., McKeen, S. A., and Rao, S. T.: Evaluation of real-time PM2.5 forecasts and process analysis for PM2.5 formation over the eastern United States using the Eta-CMAQ forecast model during the 2004 ICARTT study, J. Geophys. Res.-Atmos., 113, D06204, doi:10.1029/2007JD009226, 2008.

Zhang, Q. and Anastasio, C.: Chemistry of fog waters in California's Central Valley - Pt. 3: concentrations and speciation of organic and inorganic nitrogen, Atmos. Environ., 35, 5629-5643, 2001. 